\title{
2. EXPLANATORY NOTES: LEG 112
}

\author{
Shipboard Scientific Party ${ }^{2}$
}

Standard procedures for drilling operations and preliminary shipboard analysis of the material recovered have been regularly amended and upgraded since 1968 during investigations conducted by the Deep Sea Drilling Project (DSDP) and the Ocean Drilling Program (ODP). This chapter presents information to help the reader understand the data-gathering methods on which our preliminary conclusions are based and to help shore-based investigators select samples for further analysis. This information concerns primarily shipboard operations and analyses described in the Leg 112 site reports (this volume). Preliminary results from shipboard analysis of each individual drill site are given in the site chapters.

\section{AUTHORSHIP OF SITE REPORTS}

Authorship of the site reports is shared among the entire scientific party. Co-chief scientists and the staff scientist edited the material prepared by other individuals. The scientists responsible for a particular field also contributed "Explanatory Notes" for their specific area of study. Because of the heavy work load

\footnotetext{
${ }^{1}$ Suess, E., von Huene, R., et al., 1988. Proc. ODP, Init. Repts., 112: College Station, TX (Ocean Drilling Program).

2 Erwin Suess (Co-Chief Scientist), Oregon State University, College of Oceanography, Corvallis, OR 97331; Roland von Huene (Co-Chief Scientist), U.S. Geological Survey, Branch of Pacific Marine Geology, 345 Middlefield Rd. M/S 999, Menlo Park, CA 94025; Kay-Christian Emeis (ODP Staff Scientist), Ocean Drilling Program, Texas A\&M University, College Station, TX 77843; Jacques Bourgois, Département de Géotectonique, Université Pierre et Marie Curie, 4 Place Jussieu, 75230 Paris Cedex 05, France; José del C. Cruzado Castañeda, Petroleos del Peru S. A., Paseo de la Republica 3361, San Isidro, Lima, Peru; Patrick De Wever, CNRS, Laboratoire de Stratigraphie, Université Pierre et Marie Curie, 4 Place Jussieu, 75230 Paris Cedex 05, France; Geoffrey Eglinton, University of Bristol, School of Chemistry, Cantock's Close, Bristol BS8 1TS, England; Robert Garrison, University of California, Earth Sciences, Applied Sciences Building, Santa Cruz, CA 95064; Matt Greenberg, Lamont-Doherty Geological Observatory, Columbia University, Palisades, NY 10964; Elard Herrera Paz, Petroleos del Peru, S. A., Paseo de la Republica 3361, San Isidro, Lima, Peru; Phillip Hill, Atlantic Geoscience Centre, Bedford Institute of Oceanography, Box 1006, Dartmouth, Nova Scotia B2Y 4A2, Canada; Masako Ibaraki, Geoscience Institute, Faculty of Science, Shizuoka University, Shizuoka 422, Japan; Miriam Kastner, Scripps Institution of Oceanography, SVH, A-102, La Jolla, CA 92093; Alan E. S. Kemp, Department of Oceanography, The University, Southampton SO9 $5 \mathrm{NH}$, England; Keith Kvenvolden, U.S. Geological Survey, Branch of Pacific Marine Geology, 345 Middlefield Rd., M/S 999, Menlo Park, CA 94025; Robert Langridge, Department of Geological Sciences, Queen's University at Kingston, Ontario K7L 3A2, Canada; Nancy Lindsley-Griffin, University of Nebraska, Department of Geology, 214 Bessey Hall, Lincoln, NE 68588-0340; Janice Marsters, Department of Oceanography, Dalhousie University, Halifax, Nova Scotia B3H 4J1, Canada; Erlend Martini, Geologisch-Paläontologisches Institut der Universität Frankfurt, Senckenberg-Anlage 32-34, D-6000, Frankfurt/Main, Federal Republic of Germany; Robert McCabe, Department of Geophysics, Texas A\&M University, College Station, TX 77843; Leonidas Ocola, Laboratorio Central, Instituto Geofisico del Peru, Lima, Peru; Johanna Resig, Department of Geology and Geophysics, University of Hawaii, Honolulu, HI 96822; Agapito Wilfredo Sanchez Fernandez, Instituto Geologico Minero y Metalurgico, Pablo Bermudez 211, Lima, Peru; Hans-Joachim Schrader, College of Oceanography, Oregon State University, Corvallis, OR 97331 (currently at Department of Geology, University of Bergen, N-5000 Bergen, Norway); Todd Thornburg, College of Oceanography, Oregon State University, Corvallis, OR 97331; Gerold Wefer, Universität Bremen, Fachbereich Geowissenschaften, Postfach 330 440, D-2800 Bremen 33, Federal Republic of Germany; Makoto Yamano, Earthquake Research Institute, University of Tokyo, Bunkyo-ku, Tokyo 113, Japan.
}

of sedimentologists and biostratigraphers, a senior sedimentologist and biostratigrapher were responsible for compilation and editing of the "Lithostratigraphy" and "Biostratigraphy" sections for each site. The site chapters are organized as follows (authorship in parentheses):

\author{
Site Summary (von Huene, Suess) \\ Background and Objectives (von Huene, Suess) \\ Operations (von Huene, Suess, Hayes) \\ Lithostratigraphy (Bourgois, Emeis, Garrison, Hill, Kemp, \\ Langridge, Lindsley-Griffin, Sanchez, Thornburg, Wefer) \\ Biostratigraphy (Cruzado, De Wever, Ibaraki, Martini, Re- \\ sig, Schrader) \\ Organic Geochemistry (Eglinton, Kvenvolden) \\ Inorganic Geochemistry (Kastner) \\ Paleomagnetics (McCabe, Langridge) \\ Physical Properties (Hill, Marsters, Yamano) \\ Geophysics (von Huene, Suess, Ocola, Yamano) \\ Logging (Greenberg) \\ Summary and Conclusions (von Huene, Suess)
}

Following the text are summary sheets ("barrel sheets") of the lithologic core descriptions, biostratigraphic, and magnetostratigraphic results, and photographs of each core. Synthesis articles about pre-cruise site surveys were prepared and form a part of this volume.

\section{SURVEY AND DRILLING DATA}

The survey data used to locate the site are discussed in the individual site chapters. En route between sites and on arrival in the target areas, water depth and sub-bottom structure were observed continuously. Site surveys using a precision depth recorder and seismic profiler were performed on board JOIDES Resolution before dropping the beacon. Single-channel seismicreflection data collected during Leg 112 are presented in the "Underway Geophysics" chapter (this volume). The standard seismic sources used during the cruise were two 80 -in. ${ }^{3}$ water guns. The streamer array consisted of two 100 -m-long Teledyne streamers mounted on winches on the fantail, each containing 60 hydrophones.

The seismic system was a super-micro Masscomp 561 computer-the central unit to record, process, and display data. A 15-in.-wide Printronix high-resolution graphic printer (160 dots/ in.) processed and displayed the data in real time. The raw data were recorded on tape using a SEG-Y format and a density of 1600 bytes/in. When processed, these data can be displayed on a 22 -in.-wide Versatec plotter ( 200 dots/in.). Real-time seismic data were also displayed in analog form using two Raytheon LSR 1807M recorders having a streamer, Thoco amplifier, and Khronite filter.

Navigation data were collected using a Magnavox Combination Transit and Global Positioning satellite navigator (1107GPS) and Magnavox MX702A Transit Receiver.

Bathymetric data were obtained with both a $3.5-\mathrm{kHz}$ and a 12-kHz Precision Depth Recorder (PDR) echo-sounder, using a Raytheon PTR105B transceiver and 12 Raytheon transducers for the $3.5-\mathrm{kHz}$ data. Two Raytheon LSR $1807 \mathrm{M}$ recorders were 
used for display. Depths were read on the basis of an assumed sound velocity of $1463 \mathrm{~m} / \mathrm{s}$. Water depth (in meters) at each site was corrected (1) according to the tables of Matthews (1939) and (2) for the depth of the hull transducer $(6 \mathrm{~m})$ below sea level. In addition, depths referring to the drilling platform were assumed to be $10.5 \mathrm{~m}$ above the water line. In most cases, sonic depth and drill-string depth do not agree; we arbitrarily decided to use sonic depth for water-depth values.

\section{DRILLING CHARACTERISTICS}

Because downhole water circulation is open, drill cuttings were lost onto the seafloor and could not be recovered. The only information about the characteristics of strata in uncored or unrecovered intervals, other than from seismic data or wirelinelogging results, comes from drilling-penetration rates. Typically, the harder the layer being drilled, the slower and more difficult penetration is. However, many other factors not directly related to the hardness of the layers also determine penetration rates. For example, the parameters of bit weight, pump pressure, and revolutions per minute (all noted by the drilling recorder) also influence penetration rate.

\section{DRILLING DEFORMATION}

After splitting, some cores show signs of significant sediment disturbance. Examples of this disturbance include the downward concave bending of layers that were originally horizontal, the haphazard mixing of lumps of different lithologies, and the near-fluid state of some sediments recovered from tens to hundreds of meters below the seafloor. Core deformation probably occurs during one of three different steps: cutting, retrieval (with accompanying changes in pressure and temperature), and core handling (see "Drilling Disturbance," this chapter).

\section{SHIPBOARD SCIENTIFIC PROCEDURES}

\section{Numbering of Sites, Holes, Cores, and Samples}

ODP drill sites are numbered consecutively from the first site drilled by Glomar Challenger in 1968. A site number refers to one or more holes drilled while the ship is positioned over a single acoustic beacon. Several holes may be drilled at a single site by pulling the drill pipe above the seafloor (out of one hole), moving the ship some distance from the previous hole, and then drilling another hole.

For all ODP drill sites, a letter suffix distinguishes each hole drilled at the same site. For example, the first hole takes the site number with suffix $\mathrm{A}$, the second hole takes the site number with suffix B, and so forth. This procedure is different from that used by DSDP (Sites 1-624) but prevents ambiguity between site and hole number designations.

All ODP core and sample identifiers indicate core type. The following abbreviations are used: $\mathrm{R}=$ rotary barrel; $\mathrm{H}=$ hydraulic piston core (APC); $\mathrm{P}=$ pressure core barrel; $\mathrm{X}=$ eXtended core barrel (XCB); $\mathrm{B}=$ drill-bit recovery; $\mathrm{C}=$ center-bit recovery; $\mathrm{I}=$ in-situ water sample; $\mathrm{S}=$ sidewall sample; $\mathrm{W}=$ washed core recovery; $\mathrm{N}=$ navidrill core (used only after Leg 103); and $\mathrm{M}=$ miscellaneous material. Rotary, $\mathrm{APC}, \mathrm{XCB}$, and I cores were drilled during Leg 112 .

The cored interval is measured in meters below the seafloor (mbsf). The depth interval of an individual core is the depth below seafloor that the coring operation began to the depth that the coring operation ended. Each coring interval is as much as $9.7 \mathrm{~m}$ long, which is the maximum length of a core barrel, including core catcher. However, the coring interval may be shorter. Cored intervals are not necessarily adjacent but may be separated by drilled intervals. In soft sediment, the drill string can be "washed ahead," keeping the core barrel in place but not recovering sediment, by pumping high-pressured water down the pipe to wash the sediment out of the way of the bit and up the annulus between the drill pipe and wall of the hole. However, if thin, hard rock layers are present, one can recover "spotty" samples from these resistant layers within the washed interval.

Cores recovered from a hole are numbered serially from the top of the hole downward. Maximum full recovery from a single core is $9.7 \mathrm{~m}$ of sediment or rock in a plastic liner $(6.6 \mathrm{~cm}$ inner diameter), and about a 0.2 -m-long sample (without a plastic liner) in a core catcher (CC). The core catcher, a device at the bottom of the core barrel, prevents the core from sliding out when the barrel is being retrieved from the hole. The sediment core is then cut into 1.5 -m-long sections, which are numbered serially from the top of the core (Fig. 1). When full recovery is obtained, the sections are numbered from 1 through 7, with the last section usually shorter than $1.5 \mathrm{~m}$. For sediments and sedimentary rocks, the core-catcher sample is placed below the last section and treated as a separate section.

When recovery is less than $100 \%$, whether or not the recovered material is contiguous, the recovered sediment is placed at the top of the cored interval. The 1.5 -m-long sections are numbered serially, starting with Section 1 at the top. There are as many sections as needed to accommodate the length of the plastic liner. Sections are cut starting at the top of the recovered sediment, and the last section may be shorter than the normal 1.5$\mathrm{m}$ length. If, after the core has been split, fragments that are separated by a void appear to have been continuously in situ, a note is made in the description of the section. All voids, whether real or artificial, are curatorially preserved. Voids caused by gas expansion during core retrieval will be discussed separately.

Sample locations are designated by distance in centimeters from the top of each section to the top and bottom of the sample, respectively. Sample identifiers consist of the following information: (1) leg, (2) site, (3) hole, (4) core number and type, (5) section, and (6) interval in centimeters. For example, the sample identification number " $112-680 \mathrm{~A}-3 \mathrm{H}-2,98-100 \mathrm{~cm}$ " indicates that a sample was taken between 98 and $100 \mathrm{~cm}$ from the

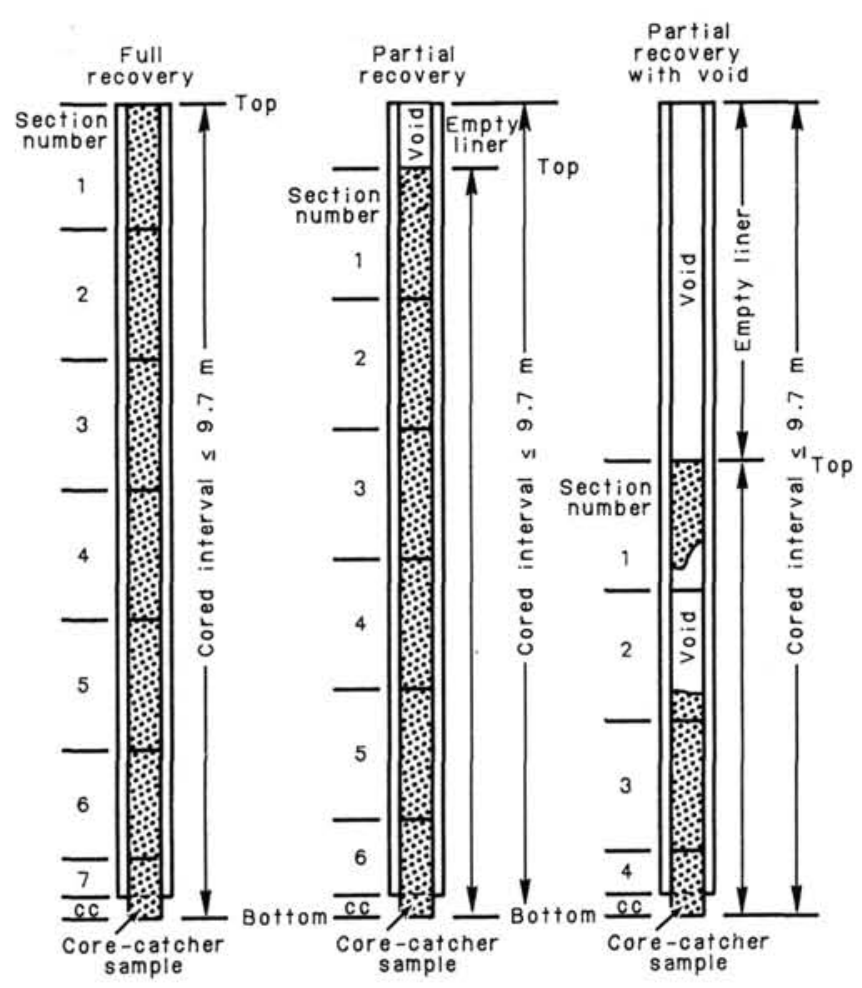

Figure 1. Examples of numbered core section. 
top of Section 2 of APC-drilled Core 3, from the first hole (A) drilled at Site 680 during Leg 112. A sample taken from between 8 and $9 \mathrm{~cm}$ in the core catcher of this core is designated " 112 $680 \mathrm{~A}-3 \mathrm{H}, \mathrm{CC}(8-9 \mathrm{~cm})$." In the case of recovery less than or equal to $100 \%$, the depth below the seafloor of a given sample is calculated as follows: depth below seafloor of the top of the core (tabulated in the "Operations" section for each site) plus $1.5 \mathrm{~m}$ for each complete section plus the distance of the sample from the top of the incomplete section. As an example, the subbottom depth of Sample 112-680B-9H-5, 98-100 cm, is $78.98 \mathrm{~m}$ below seafloor (mbsf): $72.0 \mathrm{~m}$ (top of Core 112-680B-9H) plus $6.0 \mathrm{~m}(4 \times 1.5 \mathrm{~m}$, four complete sections) plus $0.98 \mathrm{~m}$ (depth from top of Section 5). Sample depths given in this volume are rounded to one full centimeter digit. Sample requests should refer to specific intervals, however, rather than to sub-bottom depths. Note that this assignment of the subseafloor depth is an arbitrary convention; in the case of less than $100 \%$ recovery, the sample could have come from any depth within the cored interval.

Owing to the gaseous nature of the organic-rich sediments of the Peru margin, core expansion resulting from decompression during core retrieval was a common phenomenon during Leg 112. Cores from Sites 685 and 688 in particular expanded significantly, leading to "recoveries" in excess of $120 \%$ when voids separated sediment intervals. As an example, Core 112-685A18X was drilled in the interval from 156.1 to $165.6 \mathrm{mbsf}$ $(9.5 \mathrm{~m})$, but developing voids in the core liner pushed the sediment out of the liner. The voids were recorded in the Core Description Form ("barrel sheets"), so that the total length of the "recovered" section was $12.83 \mathrm{~m}$, or $135 \%$ recovery. To achieve a uniform (if arbitrary) depth notation for samples from these expanded cores, in which "recovered" section was significantly longer than cored interval, sub-bottom depths of samples from cores with more than $105 \%$ recovery can be obtained by normalizing the actual length of the core to $9.5 \mathrm{~m}$, thus making the sections shorter.

\section{Core Handling}

As soon as a core was retrieved on deck, a sample was taken from the core catcher and sent to the paleontological laboratory for an initial assessment of the age of the sample. Next, the core was placed on the long horizontal rack on the catwalk, and gas samples were taken by piercing the core liner and withdrawing gas into a vacuum-tube sampler. Voids within the core were sought as sites for the gas sampling. Some of the gas samples were stored for shore-based study, but others were analyzed immediately as part of the shipboard safety and pollution-prevention program. Next, the core was marked into section lengths; each section was labeled, and the core was cut into sections. Interstitial-water (IW) and organic-geochemistry (OG) whole-round samples were then taken as scheduled. Each section was sealed top and bottom with a blue plastic cap to identify the top of a section and a clear cap for the bottom. A yellow cap was placed on section ends from which a whole-round core sample had been removed. The caps were usually attached to the liner by coating the end of the liner and the inside rim of the end caps with acetone. Acetone treatment was not used on samples recovered for organic-geochemical study.

The cores then were carried into the laboratory and complete identifications were engraved on each section. The length of core in each section and the core-catcher sample were measured to the nearest centimeter; this information was logged into the shipboard core-log database program.

Next, cores from some holes were allowed to warm to a stable temperature (approximately $4 \mathrm{hr}$ ) before splitting. During this time, the whole-round sections were run through the gamma ray attenuation porosity evaluation (GRAPE) device for estimating bulk density and porosity (see "Physical Properties" section, this chapter; Boyce, 1976) and the $P$-wave logger (PWL). Because of the large numbers of cores handled at some sites during Leg 112, sometimes we could not run every section through the GRAPE and PWL. In such cases, we tried to run at least one section per core through the GRAPE. After the temperature of the cores had reached equilibrium, thermal conductivity was measured immediately before splitting (see "Physical Properties" section, this chapter). Again, at "busy" sites, thermal conductivity could not be measured for every section. When this happened, a measurement strategy was determined ahead of time for each site.

Core sections of relatively soft material were split lengthwise into working and archive halves. The softer cores were split with a wire, and the harder ones with a band saw. In soft sediments, some smearing of material can occur; thus, to minimize contamination, scientists analyzing samples avoided using the nearsurface part of the split core and scraped the surface with a spatula.

The working half of the core was sampled for both shipboard and shore-based laboratory studies. Each extracted sample was logged in the sampling computer program by location and by the name of the investigator receiving the sample. Records of all removed samples are kept by the ODP Curator at Texas A\&M University. The extracted samples were sealed in plastic vials or bags and labeled with a computer-printed label. Samples for microbiological shore-based studies were sealed into special containers and frozen immediately. Samples were routinely taken for shipboard analysis of (1) compressional sonic velocity using the Hamilton Frame method, (2) bulk density and water content by gravimetric analysis, and (3) percentages of calcium carbonate and organic carbon using the coulometric method. Many of these data are reported in site chapters (this volume).

The archive half was described visually. Smear slides were made from samples taken from the archive half, and thin sections were made from the working half. The archive half of each core was photographed using both black-and-white and color film.

Both halves then were placed into labeled plastic D-tubes, sealed, and transferred to cold-storage space on board the JOIDES Resolution. Leg 112 cores were shipped from Valparaiso, Chile, in refrigerated containers to cold storage at the ODP Gulf Coast Repository at Texas A\&M University, College Station, Texas.

At several Leg 112 sites, triple APC holes were drilled through the top $100 \mathrm{~m}$ of the sediment column so that chemical, physical properties, and microbiology whole-round sampling programs could be implemented. The remaining cores were not split (except where additional stratigraphic information was required) but were frozen and transported to the Gulf Coast Repository for future shore-based sampling and for core preservation and aging studies at the Ocean Drilling Program.

\section{SEDIMENT CORE DESCRIPTION FORMS ("BARREL SHEETS")}

Core Description Forms (Fig. 2) or "barrel sheets," summarize the data obtained during shipboard analysis of each core. The following discussion explains the ODP conventions used when compiling data for each part of the Core Description Form and exceptions from the standardized format necessitated by peculiarities of the sediments recovered during Leg 112 .

\section{Core Designation}

Cores are designated using leg, site, hole, and core number and type, as previously discussed (see "Numbering of Sites, Holes, Cores, and Samples," this chapter). In addition, the cored interval is specified in terms of meters below sea level 


\section{SHIPBOARD SCIENTIFIC PARTY}

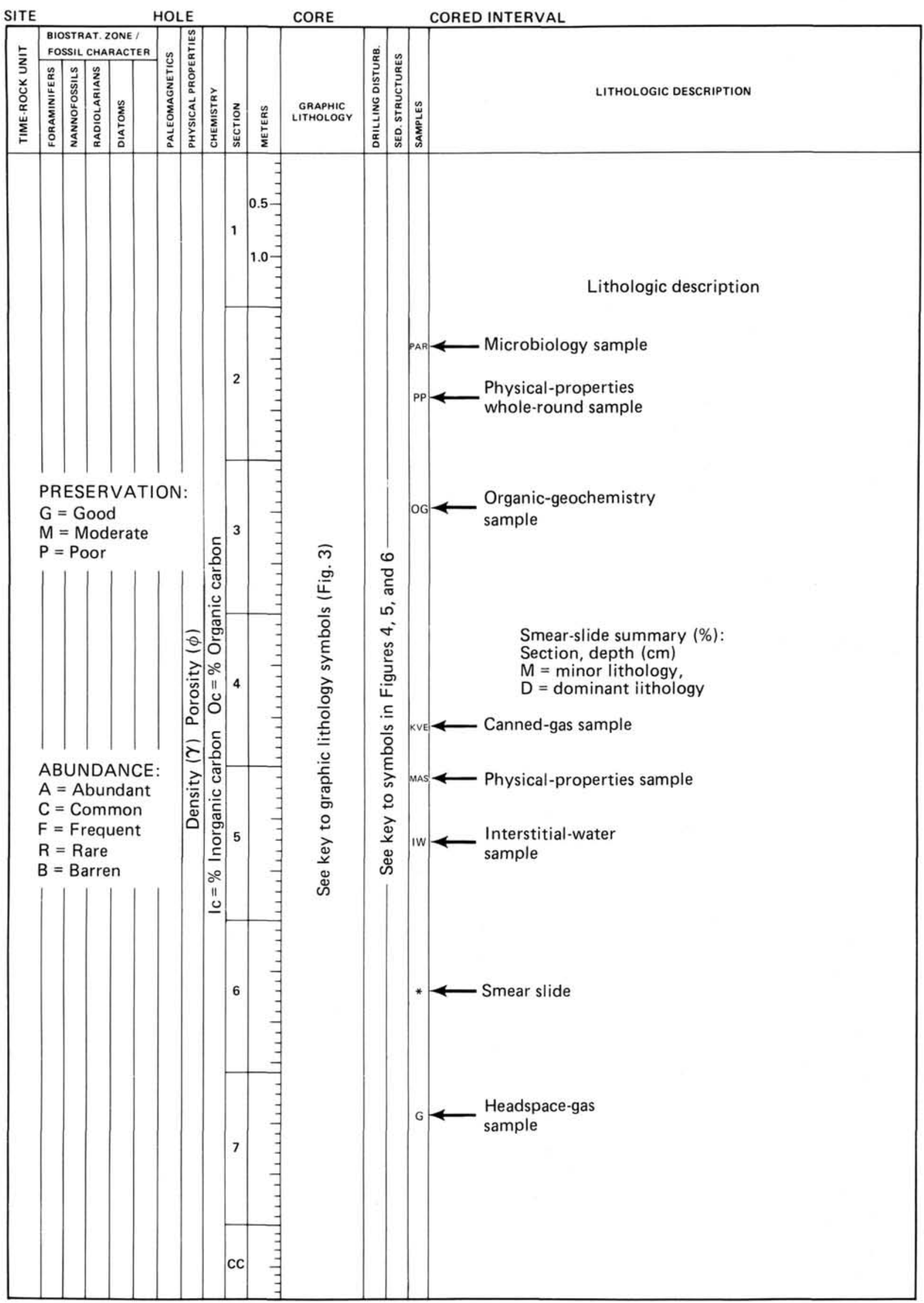

Figure 2. Core Description Form ("barrel sheets") used for sediments and sedimentary rocks. 
(mbsl) and meters below seafloor (mbsf). During Leg 112, these depths were based on sonic (precision depth recorder) measurements, as reported by the SEDCO coring technician and the ODP Operations Superintendent.

\section{Age Data}

Biostratigraphic zone assignments, as determined by shipboard paleontologists, appear on Core Description Forms under the heading "Biostratigraphic Zone/Fossil Character." Preservation and abundance of fossil groups are treated in the sitechapter "Biostratigraphy" sections. To denote samples that have been analyzed, an asterisk marks the location of an actual sample taken from the core catcher or from the core. A "B" (signifying barren) signals that no fossils of the particular group were recognized in the sample. "Insignificant" marks samples that do not contain enough specimens to assign an age unit or a zone. The geologic age determined from the paleontological and/or paleomagnetic results appears in the "Time-Rock Unit" column.

During Leg 112, diatoms, silicoflagellates, and calcareous nannofossils provided most detailed age determinations, although radiolarians, planktonic foraminifers, and magnetostratigraphic units were also used. Detailed information about zonations and terms used to report abundances and preservation appears in the "Biostratigraphy" section (this chapter).

\section{Paleomagnetic, Physical Properties, and Chemical Data}

Columns are provided on the Core Description Form to record paleomagnetic results, location of the physical-properties samples and shipboard results for undrained vane shear strength $(\gamma)$ and porosity $(\phi)$, as well as for results of inorganic-carbon (IC) and organic-carbon (OC) measurements on selected geochemistry samples. Information about shipboard procedures for collecting these types of data appears in the sections about "Physical Properties," "Paleomagnetics," and "Organic Geochemistry" (this chapter). Detailed results of these and other samples are given in the respective sections of each site, as well as tabulated results of calcium carbonate concentrations in sections covering "Lithostratigraphy."

\section{Graphic Lithology Column}

Lithologies are shown on the Core Description Form by one or more of the symbols shown in Figure 3. The symbols in a group, such as SB1 or T2, correspond to end members of sediment compositional range, such as diatomaceous ooze or terrigenous mud. For sediments that are mixtures of siliciclastic and biogenic sediments, the symbol for the siliciclastic constituents is on the right side of the column, the symbol for the biogenic constituents is on the left side of the column, and the abundances of the constituents approximately equal the percentage of the width of the graphic column that its symbol occupies. For example, the right $40 \%$ of the column may have a terrigenous mud symbol (T2), whereas the left $60 \%$ may have a diatom ooze symbol (SB1). This indicates sediment composed of $40 \%$ mud and $60 \%$ diatoms.

\section{Drilling Disturbance}

Recovered rocks, particularly soft sediments, may be slightly to extremely disturbed by drilling, and the extent of disturbance is indicated on the Core Description Form. The symbols for the six disturbance categories used for soft and firm sediments are shown in the "Drilling Disturbance" column on the Core Description Form (Fig. 4). The disturbance categories are defined as follows for soft sediments: (1) slightly deformed, bedding contacts are slightly bent; (2) moderately deformed, bedding contacts have undergone extreme bowing, and firm sediment is fractured; (3) very deformed, bedding is completely disturbed or homogenized by drilling, sometimes showing symmetrical diapirlike structure; (4) soupy, water-saturated intervals have lost all aspects of original bedding; for hard sediments: (5) slightly fractured, pieces in place, very little drilling slurry as breccia; (6) biscuited, sediment is firm and broken into chunks 5 to $10 \mathrm{~cm}$ long, pieces in place or partly displaced, but orientation can be recognized; (7) highly fragmented, pieces from interval cored and probably in correct stratigraphic sequence, but original orientation completely lost; and (8) brecciated, indurated sediment is broken into angular fragments by the drilling process, perhaps along preexisting fractures, pieces have completely lost original orientation and stratigraphic position.

\section{Sedimentary and Tectonic Structures}

We took great care to distinguish between natural structures and structures created by the coring process, although in some instances such distinctions were difficult. The locations and types of sedimentary structures in a core are shown by graphic symbols in the "Sedimentary Structures" column in the Core Description Form (Fig. 2), following standard ODP format. Figure 5 gives the explanation for these symbols.

Deformational structures also are noted in the "Sedimentary Structures" column of the Core Description Form. Figure 6 explains the structural symbols. The following terminology is used, based where possible on the A.G.I. Glossary of Geology (Bates and Jackson, 1982):

1. Extensional (normal) and compressional (reverse) faults; fault planes filled with mud are distinquished from unfilled faults;

2. Fissility is defined as the property of splitting along closely spaced parallel planes;

3. Scaly cleavage is a semi-penetrative to penetrative fabric where the rock splits along subparallel and anastomosing surfaces;

4. Fracturing and brecciation are terms used to describe breaks in rock owing to mechanical failure by stress; fractures may be visible in a confined section of core, whereas brecciation occurs where fractured rock becomes unconfined during coring or splitting of the core;

5 . Vein is the term used to describe filled extensional cracks that have limited horizontal extent; the qualifier "sigmoidal" is used where the vein shows a sigmoidal geometry on the split core surface. Use of these terms does not imply knowledge of the three-dimensional geometry (i.e., whether planar, linear, etc.), nor of the process of origin (whether dewatering, plastic intrusion, etc.). The more interpretative term "dewatering structure" overlaps with this usage but is considered valid where a vein clearly resulted from fluid escape.

6. "High-angle planar fabric" is used only at Site 685 to describe a planar fabric that cuts bedding at high angles.

Bedding, fabric, and fault-plane dips of deformed sediment were measured and noted in the sedimentary structures column of the Visual Core Description Form. These are generally not included on barrel sheets except where space allowed but are presented separately in site chapters.

\section{Samples}

Compositions of smear slides with the section and centimeter intervals of the samples are listed below the core description. The sample interval is marked by an asterisk (*) in the column titled "Samples." In addition, whole-round samples taken for interstitial-water studies (IW), organic geochemistry (OG), the canned-gas procedure (KVE), microbiology (PAR), and physical-properties measurements (MAS) are marked by the initials in this column (Fig. 2). 
PELAGIC SEDIMENTS

Siliceous Biogenic Sediments PELAGIC SILICEOUS BIOGENIC - SOFT
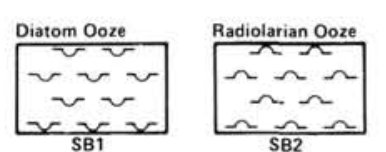

Diatom - Rad or
Siliceous Ooze

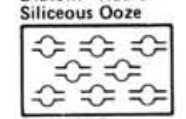

SB3

PELAGIC SILICEOUS BIOGENIC - HARD
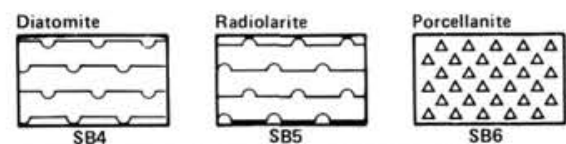

SB6

TRANSITIONAL BIOGENIC SILICEOUS SEDIMENTS

Siliceous Component $<50 \% \quad$ Siliceous Component $>50 \%$

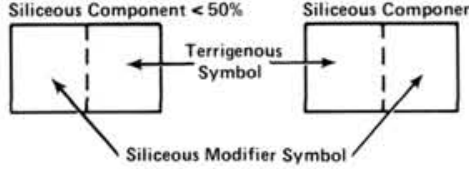

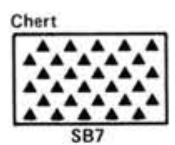

SB7

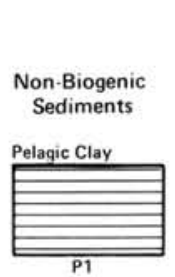

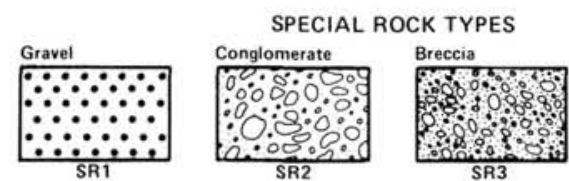
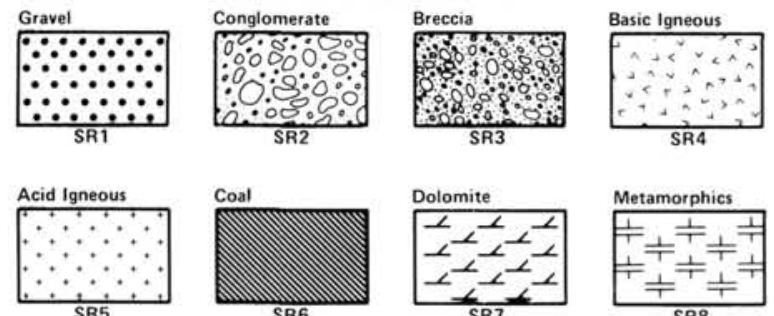

Metamorphics

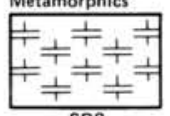

EVAPORITES

Halite
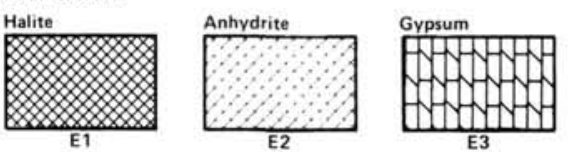

Concretions

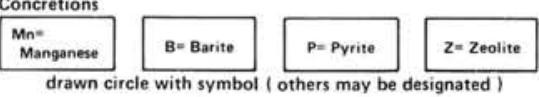

Calcareous Biogenic Sediments PELAGIC BIOGENIC CALCAREOUS - SOFT
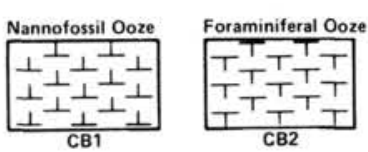

Nanno - Foram or

Foram - Nanno Ooze Calcareous Ooze

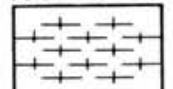

CB3

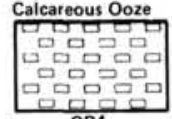

$\mathrm{CB} 4$

PELAGIC BIOGENIC CALCAREOUS - FIRM

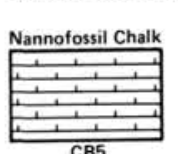

CB5

PELAGIC BIOGENIC
CALCAREOUS - HARD

Limestone
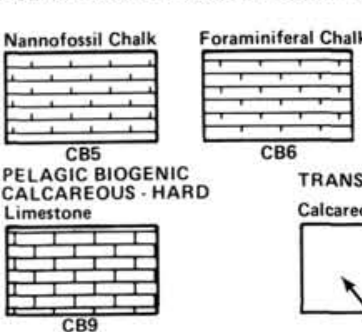

Nanno - Foram or

Foram - Nanno Chalk Calcareous Chalk
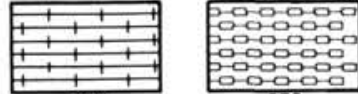

poros

CB7 CB8

Calcareous Component $<50 \%$ Calcareous Component $>50 \%$

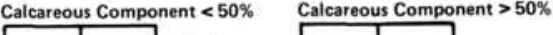

TERRIGENOUS SEDIMENTS
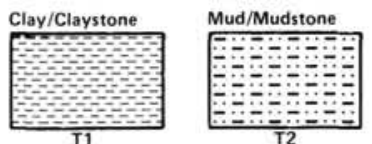

Shale (Fissile)

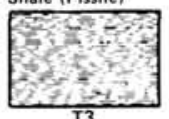

Sandy Mud/ Sandy Mudstone

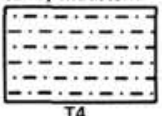

Silt/Siltstone

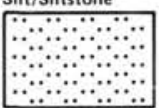

T5

Sandy Clay

Clayey Sand

….............

Sand/Sandstone

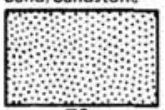

Silty Sand/

Sandy Silt

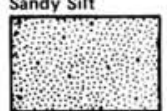

Silty Clay

Clayey Silt

VOLCANOGENIC SEDIMENTS

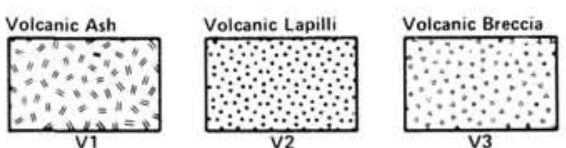

ADDITIONAL SYMBOLS

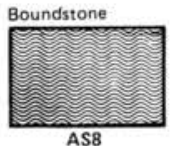

Figure 3. Explanation of lithologic symbols used in "graphic lithology" column on Core Description Form (see Fig. 2).

\section{Lithologic Description - Text}

The lithologic description appearing on each Core Description Form consists of two parts: (1) a heading that lists, in order of decreasing abundance, all sediment types observed in the core (as determined using the sediment classification system, see "Sediment Classification," this chapter) and (2) a more detailed description of characteristic features of the core, including data about color, location of sediment types in the core, significant features, and so forth.

\section{Smear Slide Summary}

A table summarizing data from smear slides and thin sections (where available) appears on each Core Description Form. The section and interval from which the sample was taken is 


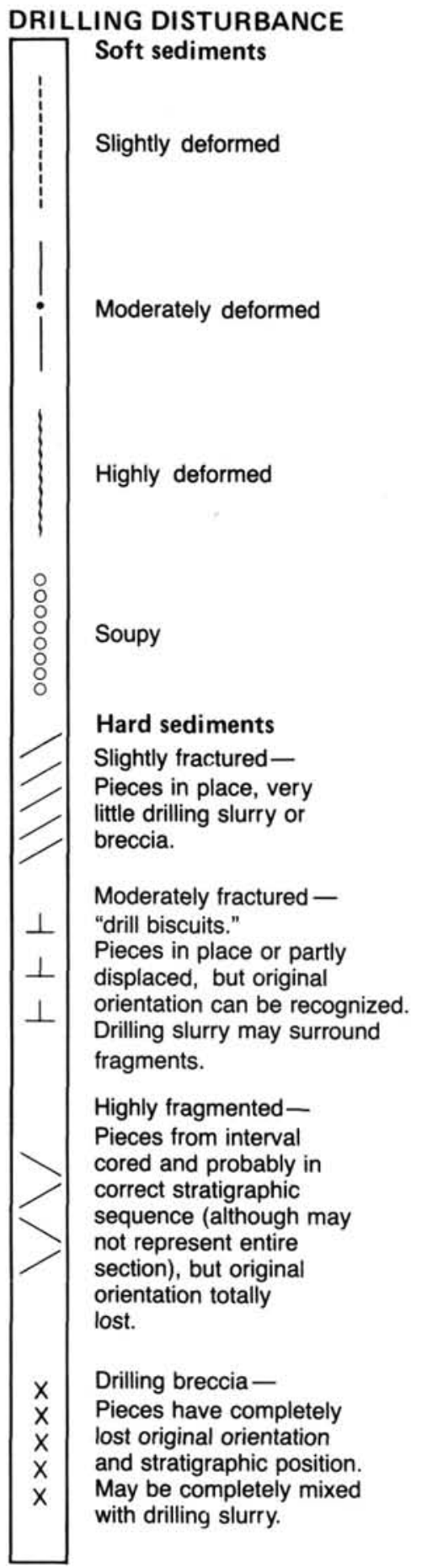

Figure 4. Drilling disturbance symbols used for Leg 112 Core Description Form.

noted, and whether the sample represents a dominant ("D") or minor ("M") lithology in the core. Besides giving estimates of textural properties (i.e., the abundance of sand, silt, and clay particles), the percentage of all identified components is listed, totaling $100 \%$. As we explain next, these estimates serve to classify and name the recovered material.

\section{SEDIMENT CLASSIFICATION}

The sediment classification scheme used during Leg 112 is a modified version of the sediment classification system that was devised by the JOIDES Sedimentary Petrology and Physical

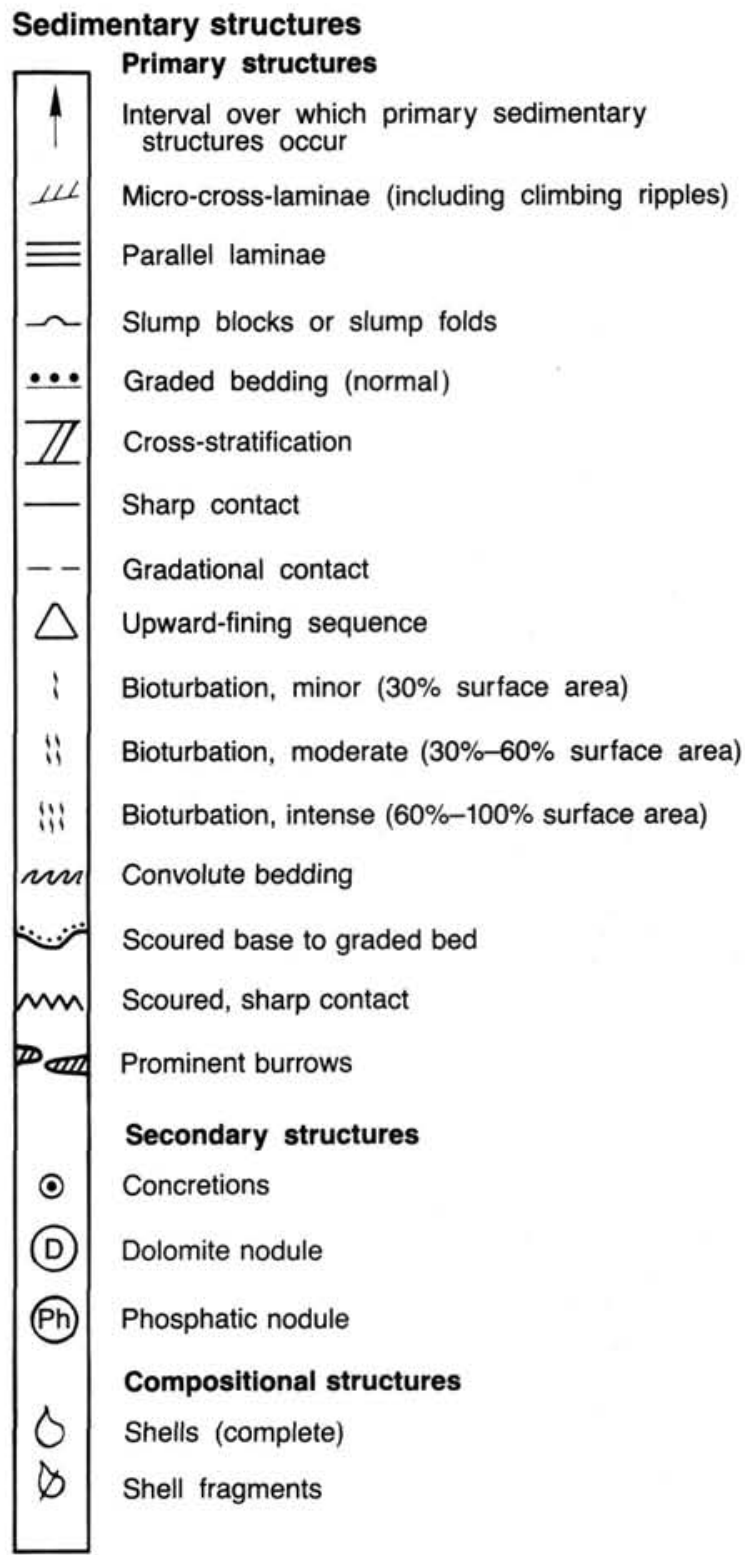

Figure 5. Sedimentary structure symbols for sediments and sedimentary rocks.

Properties Panel (SP4) and adopted for use by the JOIDES Planning Committee in March, 1974. The classification scheme used on Leg 112 incorporates many of the suggestions and terminology of Dean et al. (1985). This classification scheme is descriptive rather than genetic in nature-that is, the basic sediment types are defined on the basis of their texture and composition, rather than on the basis of their assumed origin. We estimated the texture and composition of sediment samples and the areal abundances of grain-components by examining smear slides using a petrographic microscope, and thus these may differ from more quantitative measurements of texture and composition. In some cases, however, we determined the composition of sedimentary constituents in samples by more accurate methods, such as the coulometer technique for $\mathrm{CaCO}_{3}$ and $\mathrm{X}$ ray diffractometry in the shipboard laboratories.

\section{Color}

We determined colors of the sediment by comparing them with the Geological Society of America Rock-Color Chart (Munsell Soil Color Charts). Colors were determined immediately af- 


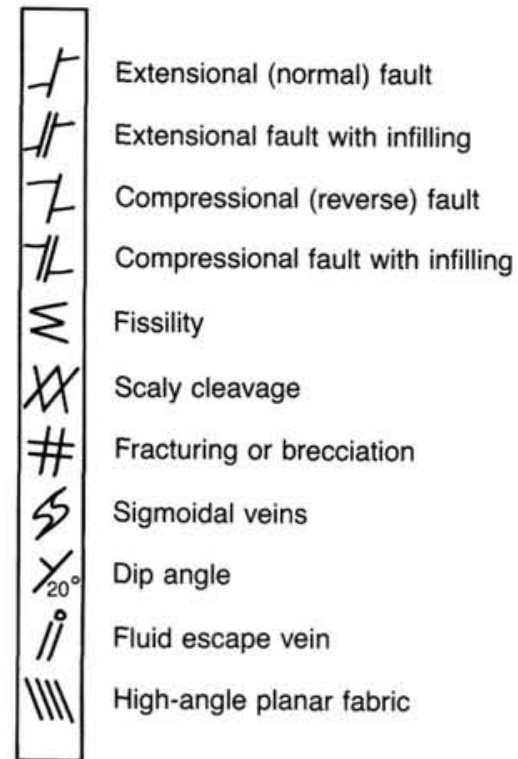

Figure 6. Graphic symbols for structural features within sediments and sedimentary rocks.

ter the cores were split and while they were still wet. Marked changes in color, particularly of originally black sediments such as those at Sites 685 and 688 , were observed over time periods as short as $1 \mathrm{hr}$ during Leg 112.

\section{General Rules of Classification}

Every sample of sediment is assigned a main name that defines its sediment type, major modifier(s) that describes the compositions and/or textures of grains that are present in abundance between $25 \%$ and $100 \%$, and minor modifier(s) that describes the compositions and/or textures of grains that are present in abundances between $10 \%$ and $25 \%$. Grains that are present in abundances between $0 \%$ and $10 \%$ are considered insignificant and are usually not included in this classification.

Minor modifiers are always listed first in the string of terms that describes a sample and are attached to the suffix "bearing," which distinguishes them from major modifiers. When two or more minor modifiers are used, they are listed in order of increasing abundance. The major modifiers are always listed second in the string of terms that describes a sample and are also listed in order of increasing abundance. The main name is the last term in the string.

The types of main names and modifiers used in this classification scheme vary among the three basic sediment types (Table 1) and are described in succeeding sections.

\section{Basic Sediment Types}

Three basic sediment types are defined on the basis of variations in the relative proportions of siliciclastic, siliceous biogenic, and calcareous biogenic grains: siliciclastic sediments, siliceous biogenic sediments, and calcareous biogenic sediments (Fig. 7).

\section{Siliciclastic Sediments}

Siliciclastic sediments are composed of more than $50 \%$ terrigenous and volcaniclastic grains (i.e., rock and mineral fragments) and less than $50 \%$ calcareous and siliceous biogenic grains.

The main name for a siliciclastic sediment describes the textures of the siliciclastic grains and its degree of consolidation. The Wentworth (1922) grain-size scale (Table 2) is used to define the textural class-names for siliciclastic sediments that contain
Table 1. Summary of nomenclature of basic sediment types.

\begin{tabular}{|c|c|c|}
\hline Minor modifiers & Major modifiers & Main name \\
\hline \multicolumn{3}{|c|}{ Siliciclastic Sediments } \\
\hline $\begin{array}{l}\text { Composition of } \\
\text { minor siliciclastic } \\
\text { grains }\end{array}$ & $\begin{array}{l}\text { Composition of } \\
\text { major siliciclastic } \\
\text { grains }\end{array}$ & $\begin{array}{l}\text { Texture of terrigenous } \\
\text { grains (sand, silt, } \\
\text { etc.) }\end{array}$ \\
\hline $\begin{array}{l}\text { Composition of } \\
\text { minor biogenic } \\
\text { grains }\end{array}$ & $\begin{array}{l}\text { Composition of } \\
\text { minor biogenic } \\
\text { grains }\end{array}$ & $\begin{array}{l}\text { Texture of } \\
\text { volcaniclastic grains } \\
\text { (ash, lapilli, etc.) }\end{array}$ \\
\hline \multicolumn{3}{|c|}{ Siliceous Biogenic Sediments } \\
\hline $\begin{array}{l}\text { Composition of } \\
\text { minor biogenic } \\
\text { grains }\end{array}$ & $\begin{array}{l}\text { Composition of } \\
\text { major biogenic } \\
\text { grains }\end{array}$ & $\begin{array}{l}\text { Ooze } \\
\text { Radiolariate } \\
\text { Diatomite } \\
\text { Porcellanite } \\
\text { Chert }\end{array}$ \\
\hline $\begin{array}{l}\text { Composition of } \\
\text { minor siliciclastic } \\
\text { grains }\end{array}$ & $\begin{array}{l}\text { Texture of major } \\
\text { siliciclastic grains }\end{array}$ & \\
\hline \multicolumn{3}{|c|}{ Calcareous Biogenic Grains } \\
\hline $\begin{array}{l}\text { Composition of } \\
\text { minor biogenic } \\
\text { grains } \\
\text { Composition of } \\
\text { minor siliciclastic } \\
\text { grains }\end{array}$ & $\begin{array}{l}\text { Composition of } \\
\text { major biogenic } \\
\text { grains } \\
\text { Composition of } \\
\text { major siliciclastic } \\
\text { grains }\end{array}$ & $\begin{array}{l}\text { Ooze } \\
\text { Chalk } \\
\text { Limestone }\end{array}$ \\
\hline
\end{tabular}

greater amounts of terrigenous grains than volcaniclastic grains. The Wentworth and Williams (1932) grain-size scale (Table 3) is used to define the textural class-names for siliciclastic sediments that contain greater amounts of volcaniclastic grains than terrigenous grains. A single textural class name (e.g., "sand," "coarse silt," "ash") is used when one textural class is present in abundances in excess of $90 \%$. When two or more textural classes are present in abundances greater than $10 \%$, they are listed in order of increasing abundance (e.g., "silty sand," "ashy clay"). The term "mud" is used to describe mixtures of silt and clay. Where

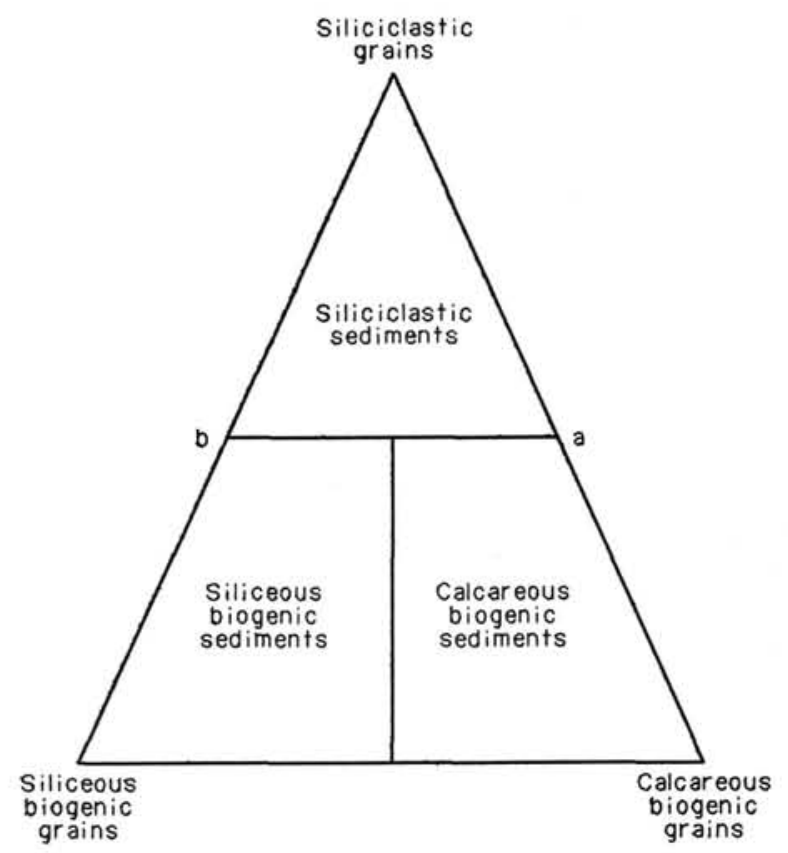

Figure 7. Ternary diagram that defines the three basic sediment types, based on the relative proportions of siliciclastic, siliceous biogenic, and calcareous biogenic grains. 
Table 2. Grain sizes used to classify terrigenous sediments (from Wentworth, 1972).

\begin{tabular}{|c|c|c|c|c|c|}
\hline \multicolumn{6}{|c|}{ Grain sizes } \\
\hline \multicolumn{2}{|r|}{$(\mathrm{mm})$} & \multirow[t]{2}{*}{$(\mu \mathrm{m})$} & \multirow{2}{*}{$\begin{array}{r}\text { phi }(\phi) \\
0.20\end{array}$} & \multicolumn{2}{|l|}{ Wentworth class } \\
\hline & & & & & \\
\hline & 4096 & & 0.12 & Boulder $(0.8$ to $0.12 \phi)$ & \\
\hline & 1024 & & 0.10 & & \\
\hline & 256 & & 0.8 & & \\
\hline & 64 & & 0.6 & Cobble $(0.6$ to $0.8 \phi)$ & Gravel \\
\hline & 16 & & 0.4 & Pebble ( 0.2 to $0.6 \phi)$ & \\
\hline & 4 & & 0.2 & & \\
\hline & 3.36 & & 1.75 & & \\
\hline & 2.83 & & 1.5 & Granule & \\
\hline & 2.38 & & 1.25 & & \\
\hline & 2.00 & & 1.0 & & \\
\hline & 1.68 & & 0.75 & & \\
\hline & 1.41 & & 0.5 & Very coarse sand & \\
\hline & 1.19 & & 0.25 & & \\
\hline & 1.00 & & 0 & & \\
\hline & 0.84 & & 0.25 & & \\
\hline & 0.71 & & 0.5 & Coarse sand & \\
\hline & 0.59 & & 0.75 & & \\
\hline \multirow[t]{4}{*}{$1 / 2$} & 0.50 & 500 & 1 & & \\
\hline & 0.42 & 420 & 1.25 & & \\
\hline & 0.35 & 350 & 1.5 & Medium sand & Sand \\
\hline & 0.30 & 300 & 1.75 & & \\
\hline \multirow[t]{4}{*}{$1 / 4$} & 0.25 & 250 & 2 & & \\
\hline & 0.210 & 210 & 2.25 & & \\
\hline & 0.177 & 177 & 2.5 & Fine sand & \\
\hline & 0.149 & 149 & 2.75 & & \\
\hline \multirow[t]{4}{*}{$1 / 8$} & 0.125 & 125 & 3 & & \\
\hline & 0.105 & 105 & 3.25 & & \\
\hline & 0.088 & 88 & 3.5 & Very fine sand & \\
\hline & 0.074 & 74 & 3.75 & & \\
\hline \multirow[t]{4}{*}{$1 / 16$} & 0.0625 & 63 & 4 & & \\
\hline & 0.053 & 53 & 4.25 & & \\
\hline & 0.044 & 44 & 4.5 & Coarse silt & \\
\hline & 0.037 & 37 & 4.75 & & \\
\hline $1 / 32$ & 0.031 & 31 & 5 & & \\
\hline $1 / 64$ & 0.0156 & 15.6 & 6 & Medium silt & \\
\hline $1 / 128$ & 0.0078 & 7.8 & 7 & Fine silt & Mud \\
\hline \multirow{7}{*}{$1 / 256$} & 0.0039 & 3.9 & 8 & Very fine silt & \\
\hline & 0.0020 & 2.0 & 9 & & \\
\hline & 0.00098 & 0.98 & 10 & Clay & \\
\hline & 0.00049 & 0.49 & 11 & & \\
\hline & 0.00024 & 0.24 & 12 & & \\
\hline & 0.00012 & 0.12 & 13 & & \\
\hline & 0.00006 & 0.06 & 14 & & \\
\hline
\end{tabular}

Table 3. Scale for volcaniclastic grains.

\begin{tabular}{|c|c|c|}
\hline $\begin{array}{l}\text { Grain size } \\
(\mathrm{mm})\end{array}$ & $\begin{array}{l}\text { Unconsolidated } \\
\text { grains }\end{array}$ & $\begin{array}{l}\text { Consolidated } \\
\text { grains }\end{array}$ \\
\hline$>64$ & Volcanic rubble & Volcanic breccia \\
\hline 64 to 4 & Volcanic lapilli & Volcanic lapillistone \\
\hline$<4$ & Volcanic ash & Volcanic tuff \\
\hline
\end{tabular}

mud shows an advanced state of lithification, the term "mudstone" is used. Cemented sands are designated "sandstone," preceded by a qualifier, such as "calcareous" or "dolomitic" to indicate the nature of the cement.

The major and minor modifiers for a siliciclastic sediment describe the compositions of the siliciclastic grains as well as the compositions of accessory biogenic grains. The compositions of terrigenous grains can be described by terms such as "quartz," "feldspar," "glauconite," or "lithic" (for rock fragments), and the compositions of volcaniclastic grains can be described by the terms "vitric" (glass), "crystalline," or "lithic." All compositional modifiers are followed by the suffix "-bearing" when the grain-component is present in minor (10\% to $25 \%)$ amounts. The compositions of biogenic grains can be described by the terms enumerated next.

\section{Siliceous Biogenic Sediments}

Siliceous biogenic sediments are composed of less than $50 \%$ siliciclastic grains and more than $50 \%$ biogenic grains but contain greater proportions of siliceous biogenic grains than calcareous biogenic grains.

The main name of a siliceous biogenic sediment describes its composition and degree of lithification, using the following terms:

1. "ooze"-soft, unconsolidated siliceous biogenic sediment.

2. "radiolarite"-hard, consolidated siliceous biogenic sediment composed predominantly of radiolarians.

3. "diatomite"-hard, consolidated siliceous biogenic sediment composed predominantly of diatoms.

4. "porcellanite"-a dull, white, porous indurated siliceous biogenic sediment.

5. "chert"-a lustrous, conchoidally fractured, indurated siliceous biogenic sediment.

The major and minor modifiers for a siliceous biogenic sediment describe the compositions of the siliceous biogenic grains, as well as the compositions of accessory calcareous biogenic grains and the textures of accessory siliciclastic grains. The compositions of siliceous biogenic grains can be described by the terms "radiolarian," "diatom," "spicular," and "siliceous" (for unidentifiable siliceous biogenic debris), followed by the suffix "-bearing" when the component is present in minor $(10 \%$ to $25 \%$ ) amounts. The compositions of accessory calcareous grains are described by the terms discussed next; the textures of accessory terrigenous grains were described by terms discussed previously.

\section{Calcareous Biogenic Sediments}

Calcareous biogenic sediments are composed of less than $50 \%$ siliciclastic grains and more than $50 \%$ biogenic grains but contain greater proportions of calcareous biogenic grains than siliceous biogenic grains.

The main name of a calcareous biogenic sediment describes its degree of consolidation, using the terms "ooze" (soft, unconsolidated), "chalk" (partially lithified), and "limestone" (hard, lithified).

The major and minor modifiers for a calcareous biogenic sediment describe the compositions of calcareous biogenic grains, as well as the compositions of accessory siliceous biogenic grains and the textures of accessory siliciclastic grains.

The compositions of calcareous biogenic grains are described by the terms "foraminifer," "nannofossil," or "calcareous" (for unidentifiable carbonate fragments), followed by the suffix "-bearing" when the grain-components are present in minor $(10 \%$ to $25 \%)$ amounts. The compositions of siliceous biogenic grains and the textures of siliciclastic grains are described by the terms discussed previously.

\section{Special Rock Types}

The definitions and nomenclatures of special rock types are not included in the previous section, but adhere as closely as possible to conventional terminology. Two special rock types were particularly important during Leg 112 . Dolomite occurred as beds and nodules and was designated by a " $D$ " in the "Sedimentary Structures" column of the Core Description Form ("barrel sheets"). The degree of lithification was noted in the core description as "friable" where the rock showed only partial lithification, or "lithified" where fully cemented. Phosphate-rich sediments also were present, designated by " $\mathrm{Ph}$ " in the "Sedimentary Structures" column (distinct from " $\mathrm{P}$," which is commonly used during ODP legs to designate pyrite). Two distinc- 
tive types of phosphatic materials were recovered during Leg 112. F-phosphate is the designation given to friable, generally light-colored lenses and layers of fine-grained carbonate fluorapatite (francolite). The term D-phosphate is used for those phosphatic peloids, nodules, gravels, and phosphatic hardgrounds composed mainly of dense, hard, dark-colored francolite. The term "phosphorite" is restricted to layers that are composed mainly of phosphatic grains.

\section{BIOSTRATIGRAPHY}

\section{General Remarks}

The general correlation of biostratigraphic zones with the magnetic polarity reversal record, the seafloor anomalies, and an absolute time scale was adopted from DSDP Legs 85 and 33 for the Eocene (Schlanger et al., 1976). For discussion of correlation of Chron 11 with Anomaly 5 see Barron et al. (1985b). Each microfossil zonation was then fit into this reversal/anomaly scheme for the Quaternary to middle Eocene (Fig. 8). Age assignments are based on core-catcher samples. In some cases, additional samples were taken in between core catchers to narrow certain time intervals. Biostratigraphic zones thus recognized were entered in the barrel sheets of each core. In the columns for each fossil group, an asterisk $\left({ }^{*}\right)$ denotes a sample investigated in the core catcher and elsewhere. If the sample was found barren of a particular group of fossils, it is noted behind the asterisk. If a column is not marked with this signature, no sample was studied.

\section{Individual Fossil Groups}

\section{Diatoms}

The zonations of Akiba (1985), Akiba and Yanagisawa (1985), Barron (1985a), and Burckle (1972) were used for the Quaternary to lower Miocene. Additional datum planes were taken from Schrader (1973) and various references from Californian sections. Eocene to Oligocene planktonic diatom stratigraphy was adopted from Fenner $(1984,1985)$.

Preparation followed the routines developed on board using smear-slide techniques with Hyrax as a mounting medium (see Schrader, 1971; Schrader and Gersonde, 1978).

Abundance calls are based on abundances of individual species within the diatom assemblage, rarer occurrences are based on field-of-view counting techniques where the average abundance of the commoner species per field of view was determined, and a count of fields of views and assessment of the occurrence of the rarer species also was determined. The following convention was adopted:

$$
\begin{aligned}
& \mathrm{M}=\text { mass occurrence (floods) },>75 \% \\
& \mathrm{~A}=\text { abundant, } 50 \%-75 \% \\
& \mathrm{C}=\text { common, } 25 \%-50 \% \\
& \mathrm{~F}=\text { few, } 1 \%-25 \% \\
& \mathrm{R}=\text { rare },<1 \% \\
& \mathrm{~T}=\text { trace, present in very small amounts } \\
& \mathrm{B}=\text { barren, no diatoms present }
\end{aligned}
$$

Preservation of siliceous microfossils was classified into four major categories based on the presence of complete or broken, thinly silicified or heavily silicified frustules:

$$
\begin{aligned}
\mathrm{E}= & \text { excellent, very well preserved with numerous delicate } \\
& \text { frustules } \\
\mathrm{G}= & \text { good, well preserved with numerous Chaetoceros, } \\
& \text { Thalassiosira } \\
\mathrm{M}= & \text { moderate, some thinly silicified frustules present } \\
\mathrm{P}= & \text { poor, only heavily silicified frustules present }
\end{aligned}
$$

Occurrences of displaced or in-situ benthic diatoms will be noted to assess the amount of displacement of shallow (less than $100 \mathrm{~m}$ of water depth) material by determining the proportion of planktonic vs. benthic diatoms.

\section{Silicoflagellates, Ebridians, and Actiniscidians}

Owing to current conditions off Peru, the silicoflagellate assemblages were expected to be similar to those found in the southwest Pacific around New Zealand; the zonation applied during DSDP Leg 90 was used (Locker and Martini, 1986a). For the Oligocene and Eocene, zonations outlined in Perch-Nielsen (1975; Leg 29) and Martini and Mueller (1976; Leg 38) are adequate. Position of zonal boundaries with regard to magnetostratigraphy and chrons is shown in Figure 9 and is based on data obtained through correlation with calcareous nannoplankton. Ebridians and actiniscidians are counted with the silicoflagellates, and the zonation outlined in Locker and Martini (1986b) was used.

Preparation of silicoflagellates followed the standard smearslide technique. To define the abundances, a 120 -mm traverse was conducted on the smear slides. Five categories were used:

$$
\begin{array}{ll}
1 \text { (very rare) } & =1 \text { specimen } \\
2 \text { (rare) } & =2 \text { to } 5 \text { specimens } \\
3 \text { (few) } & =6 \text { to } 15 \text { specimens } \\
4 \text { (common) } & =16 \text { to } 50 \text { specimens } \\
5 \text { (abundant) } & =>50 \text { specimens. }
\end{array}
$$

\section{Calcareous Nannoplankton}

The standard calcareous nannoplankton zonation (Martini, 1971; Martini and Mueller, 1986) was used at all sites to identify nannoplankton zones in the Quaternary and Tertiary. Additional data were available for the Quaternary using the succession of events outlined by Gartner (1977). For comparison between the zonal schemes of Martini (1971) and Okada and Bukry (1980), the paper by Martini and Mueller (1986) on current Tertiary and Quaternary calcareous nannoplankton stratigraphy and correlations was consulted.

Regarding correlation to magnetostratigraphy and chrons, we more or less followed the scheme used during DSDP Leg 85, except for a corrected version as to the change of anomaly 5 to chron 11 instead of chron 9.

Preparation followed the standard smear-slide technique, in which a small amount of sediment is dispersed in some drops of water and smeared with a flat toothpick onto a glass slide. The material is then dried and mounted in Canada balsam.

Abundances of species were defined as follows:

$M=$ mass occurrence, $>75 \%$ in a given field

$\mathrm{A}=$ abundant, $>50 \%$ in a given field

$\mathrm{C}=$ common, $>10 \%$ in a given field

$\mathrm{F}=$ few, $>1 \%$ in a given field

$\mathrm{R}=$ rare, $<1 \%$ in a given field.

Preservation was described using three categories:

$\mathrm{G}=$ good, no or only minor signs of dissolution or overgrowth of placoliths and discoasters

$\mathbf{M}=$ moderate, slight to moderate dissolution of placoliths, discoasters, and others or slight to moderate overgrowth, especially on discoasters and other ortholithic forms

$\mathrm{P}=$ poor, severe dissolution in placoliths with abundant broken specimens or heavy overgrowth of discoasters and sphenoliths. 


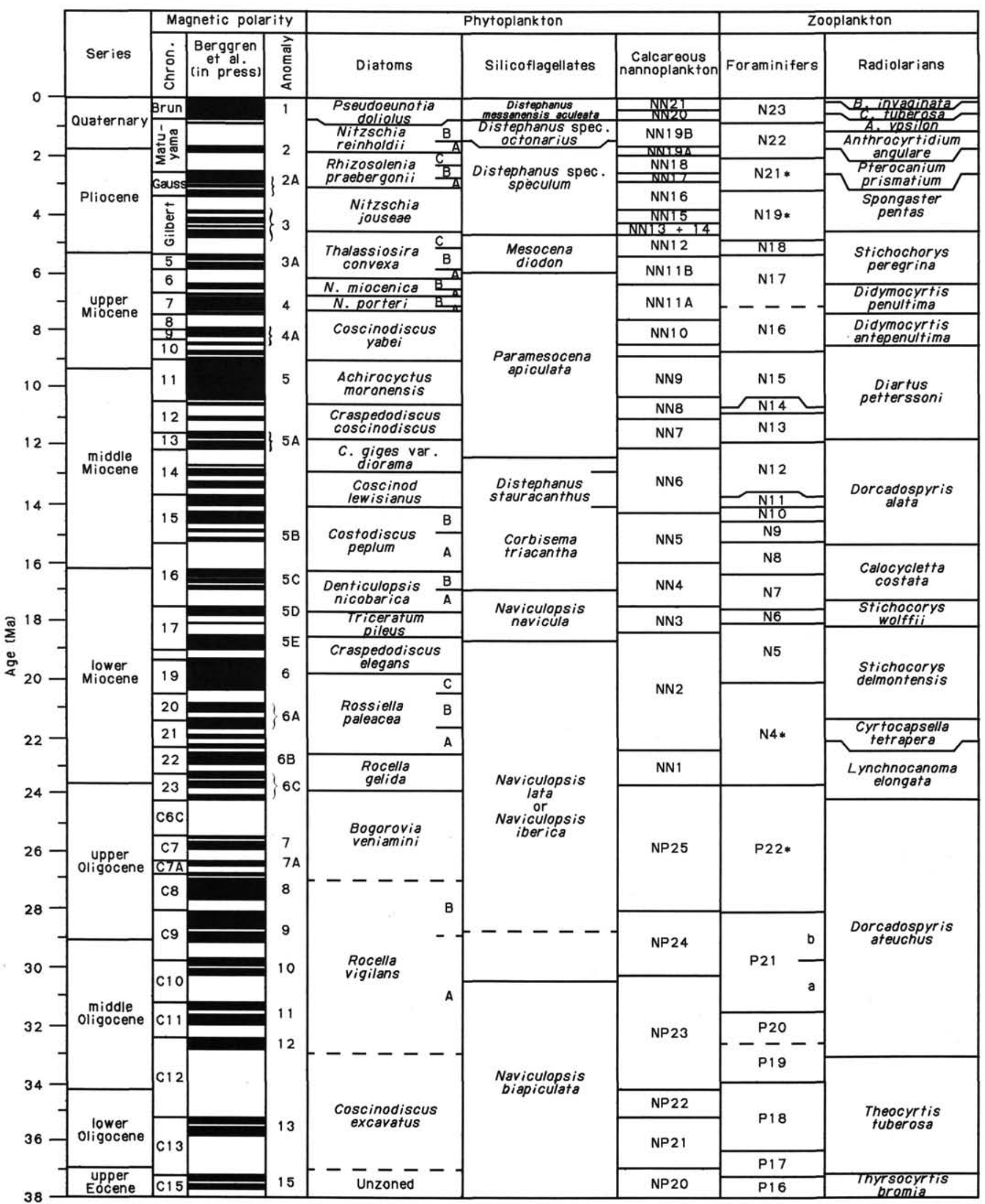

Figure 8. Leg 112 biostratigraphic "standard." 


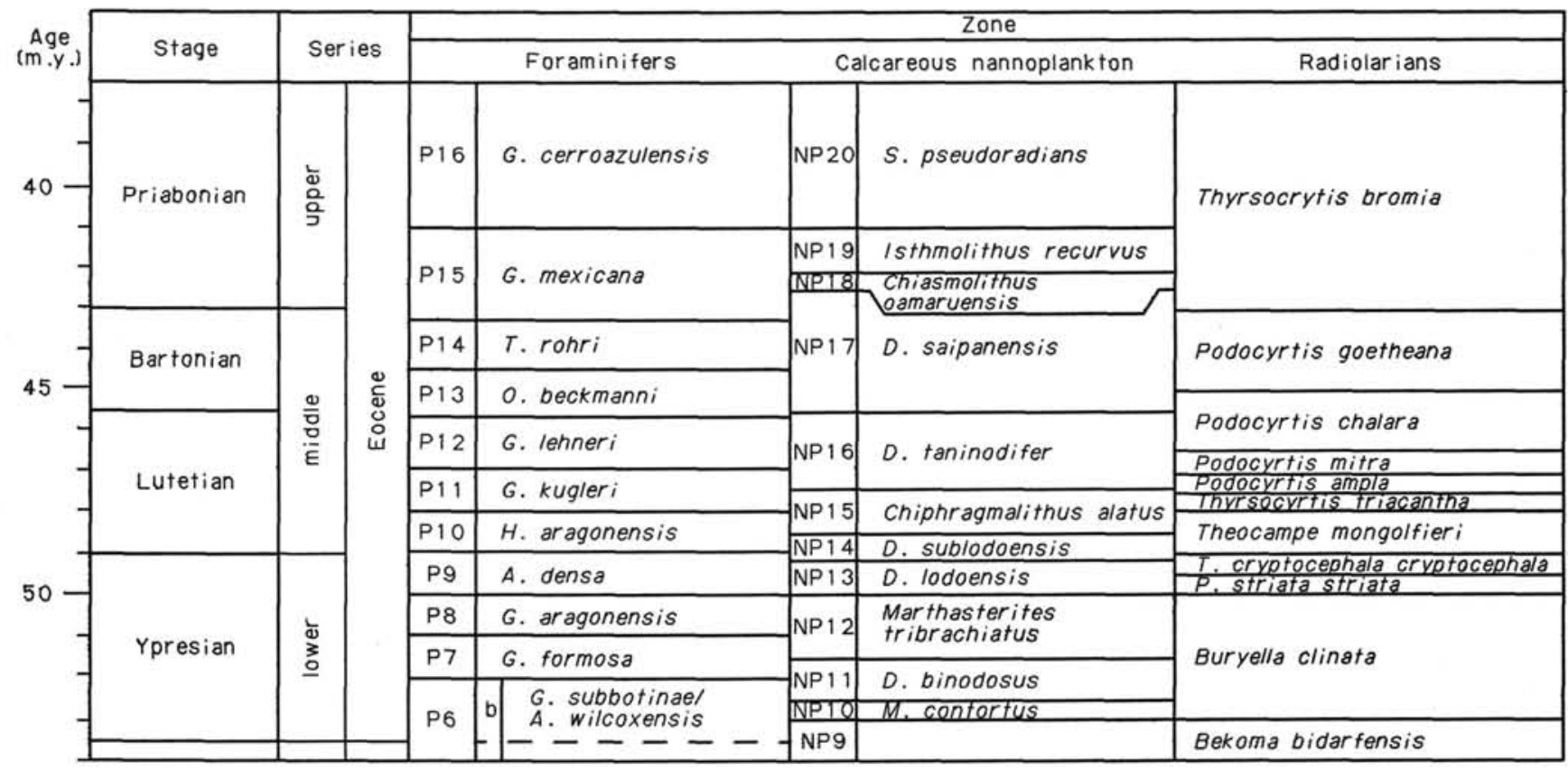

Figure 9. Leg 112 biostratigraphic zonation for the Eocene.

\section{Radiolarians}

The radiolarian zones of Nigrini (1971) and Riedel and Sanfilippo (1978) were used for the Cenozoic. Samples were prepared according to conventional techniques, that is, they were washed with hydrogen peroxide and Calgon and with $10 \%$ hydrochloric acid when necessary. Residues were sieved with a 63$\mu \mathrm{m}$ sieve. Slides were mounted with Canada balsam.

Estimates of abundances for Cenozoic samples were judged using the following terms: "abundant" (more than 500 specimens), "common" (51 to 500), "few" (11 to 50), "rare" (4 to $100)$, "very rare" (less than 4 specimens per slide), and "uncertain identification."

\section{Planktonic Foraminifers}

The foraminifer zonation of Blow (1969) was used exclusively; in addition, the biostratigraphic interpretation (Jenkins and Orr, 1972) of faunal assemblages from the equatorial $\mathrm{Pa}-$ cific (DSDP Leg 9) and Poore et al.'s (1984) correlation of foraminifer zones to the magnetic reversal record from the south Atlantic (DSDP Leg 73) were incorporated. The correlation of zones to the reversal record proposed by Berggren et al. (1985) was used to infer absolute ages of zones and datum levels.

Wet samples were sieved using a $63-\mu \mathrm{m}$ sieve; the residue was dried under infrared lamps. Planktonic foraminifer species abundance was determined from the total planktonic foraminifer assemblage and the following abundance calls:

$$
\begin{aligned}
& \mathrm{A}=\text { abundant },>30 \% \\
& \mathrm{C}=\text { common, } 15 \% \text { to } 30 \% \\
& \mathrm{~F}=\text { few, } 3 \% \text { to } 15 \% \\
& \mathrm{R}=\text { rare, }<3 \% .
\end{aligned}
$$

The states of preservation of the assemblages were divided into three major categories:

$\mathrm{G}=$ good, more than $90 \%$ of specimens unbroken

$\mathrm{M}=$ moderate, $30 \%-90 \%$ of specimens show dissolution

$\mathrm{P}=$ poor, fragments and broken individuals dominate.

\section{Benthic foraminifers}

Benthic foraminifers were used for estimates of paleobathymetry, following data about the distribution of modern species in the area (Ingle et al., 1980; Resig, 1981) and of fossil species in California Cenozoic deposits (Ingle, 1973; 1980).

Biofacies included the following:

$\begin{array}{ll}\text { Inner Shelf } & <50 \mathrm{~m} \\ \text { Outer Shelf } & 50-150 \mathrm{~m} \\ \text { Upper Bathyal } & 150-500 \mathrm{~m} \\ \text { Upper Middle Bathyal } & 500-1500 \mathrm{~m} \\ \text { Lower Middle Bathyal } & 1500-2000 \mathrm{~m} \\ \text { Lower Bathyal } & 2000-4000 \mathrm{~m} \\ \text { Abyssal } & >4000 \mathrm{~m} .\end{array}$

The low-oxygen biofacies was characterized by the prevalence of Bolivina seminuda humilis and various other bolivinids, buliminids, and uvigerinids.

Samples for benthic foraminifers were processed by wet sieving the sample through a sieve having $63-\mu \mathrm{m}$ openings and by drying under an infrared lamp. Abundances of benthic foraminifers were estimated using the terms "abundant," "common," or "few" if thousands, hundreds, or tens of specimens were present, respectively, and "rare" if only several specimens were present in the sand fraction of the sample. Frequency of benthic species was designated as follows:

$$
\begin{aligned}
& \mathrm{R}=\text { rare },<1 \% \\
& \mathrm{~F}=\text { few, } 1 \%-5 \% \\
& \mathrm{C}=\text { common, } 5 \%-10 \% \\
& \mathrm{~A}=\text { abundant },>10 \% .
\end{aligned}
$$

Preservation was determined by the degree of breakage and etching of the benthic tests using the following terms: Poor, if breakage and etching were prevalent; Moderate, if about $50 \%$ of the assemblage was broken or etched; and Good, if most specimens were intact. 


\section{PALEOMAGNETISM}

All paleomagnetic samples collected during Leg 112 were in the form of plastic minicubes $\left(6 \mathrm{~cm}^{3}\right)$. Samples were taken from every section of core that was not too disturbed by drilling. Sedimentation rates encountered during the cruise were high enough to provide sufficient detail, although more detailed sampling was undertaken in interesting intervals. Sampling was discontinued when the intensity of magnetization of the samples fell to $<0.50 \mathrm{~mA} / \mathrm{m}$, the sensitivity limit of our instruments. Low intensities, coupled with the fact that core recovery generally trailed off when the switch was made to XCB coring, left gaps in the record and precluded our obtaining a useful record for the lower sections with available instruments.

Remanent magnetic properties (intensity, inclination, and declination) were measured with a Molspin Minispin portable spinner magnetometer. This magnetometer interfaces with a DEC PRO-350 personal computer using software written by Yozo Hamano during Leg 109 and subsequently modified by John Tauxe. Some magnetic susceptibility measurements were conducted using the Bartington Instruments M.S.1 magnetic-susceptibility meter. Alternating-field demagnetization was performed in steps of $150,200,300$, and 400 Oe with a Schonstedt GSD-1 single-axis demagnetizer. Where weaker samples were encountered, our demagnetization steps were lowered to 20,50 , 100 , and $150 \mathrm{Oe}$. Selection of useable data involved choosing samples that ideally showed the following characteristics:

1. An Angular Standard Deviation of less than $15^{\circ}$ for a measurement. Usually, angular standard deviations were less than $10^{\circ}$ for cores above the Brunhes/Matuyama boundary.

2. A unidirectional decay of their remanence toward the origin on $\mathrm{Zijderveld} \mathrm{plots,} \mathrm{indicating} \mathrm{a} \mathrm{single} \mathrm{component} \mathrm{of} \mathrm{mag-}$ netization, or a linear decay on Zijderveld plots, indicating a well-defined direction of magnetization with a second magnetization present.

3. Alternating-field demagnetization was effective for decreasing intensity to less than one-half that of the natural remanent magnetization (NRM).

4. An NRM greater than $0.1 \mathrm{~mA} / \mathrm{m}$.

These criteria were relaxed from time to time during the cruise. As the sites are located south of the equator, discussions about normal polarity refer to samples with negative inclinations.

\section{ORGANIC GEOCHEMISTRY}

The following instrumentation and procedures were used during Leg 112 (1) to measure the concentrations of hydrocarbon gases, (2) to estimate the amounts of long-chain alkenones, (3) to test for organic pigments, and (4) to determine the quantity and quality of organic matter in the sediments.

\section{Hydrocarbon Gases}

Compositions and concentrations of hydrocarbon gases were measured using two different gas chromatographs: Hach-Carle AGC Series 100 (Model 211), referred to as HC, and HewlettPackard 5980A with Option 820 (Natural Gas Analyzer) coupled with Headspace Sampler (Model 19395A) and referred to as HP. The HC was attached to a Hewlett-Packard Model 3393A Integrator that allowed the single measurement of gas concentrations over six orders of magnitude after appropriate calibration. The HC instrument is designed to measure accurately and rapidly the concentrations of methane, ethane, and propane in $5 \mathrm{~min}$. Ethene is resolved from ethane and can also be quantified. The $\mathrm{HC}$ has the following characteristics:

1. A 1.0-mL sample loop with column backflush.

2. Columns, $1 / 8$ in. $\times 6 \mathrm{ft}, 80 \%$ Poropak $\mathrm{N}+$ Poropak $\mathrm{Q}$ $(80 / 100$ mesh) and $1 / 8$ in. $\times 8 \mathrm{ft}, 10 \%$ Carbowax $20 \mathrm{M}$ on
Chromasorb W-HP (80/100 mesh). Only the first column was used for routine analyses.

3. Flame ionization detector.

4. Conditions, isothermal at $90^{\circ} \mathrm{C} ; \mathrm{He}, 60 \mathrm{psig}$; air, $10 \mathrm{psig}$; $\mathrm{H}_{2}, 30$ psig.

The HP system was designed to measure automatically the concentrations of components of natural gases in a headspace analyzer. Each analysis was completed in about $20 \mathrm{~min}$ and reports, through both a Hewlett-Packard Model 3392A Integrator and a Hewlett-Packard Laboratory Automation System (Model 3350 ), the concentrations of hydrocarbon gases through hexane. Currently, the reporting system is limited in that it requires the use of different methods, depending on the concentrations of the components in the gas mixtures. The need for different methods increases analysis time and the possibility of error. Because of these limitations, we relied mainly on the $\mathrm{HC}$ during Leg 112. The HP system with its accessories has the following characteristics:

1. A $0.25-\mathrm{mL}$ sample loop with automatic sample injection and backflush; sample bath at $70^{\circ} \mathrm{C}$.

2. Columns of $1 / 8$ in. $\times 6 \mathrm{ft}, 35 \%$ DC200 methyl silicone fluid ( $80 / 100$ mesh), $1 / 8$ in. $\times 6 \mathrm{ft}$, Poropak Q (80/100 mesh), and $1 / 8$ in. $\times 10 \mathrm{ft}, 13 \mathrm{X}$ Molecular Sieve (45/60 mesh). Only the first two columns were used for making routine analyses.

3. Thermal conductivity and flame ionization detectors.

4. Conditions, isothermal at $110^{\circ} \mathrm{C} ; \mathrm{He}, 94 \mathrm{psig}$; air, $36 \mathrm{psig}$; $\mathrm{H}_{2}, 20$ psig.

During Leg 112 two different procedures were used to extract hydrocarbon gases from sediment samples. In one procedure, the can procedure, a measured length (approximately $5 \mathrm{~cm}$ ) of whole-round core was placed in a container along with enough seawater so that a $100-\mathrm{cm}^{3}$ headspace remained when the container was sealed. This headspace was purged with helium, after which the can was shaken, and gases were extracted into the helium-filled headspace. Part of this gas mixture was analyzed by gas chromatography. The following calculations were used:

Volume of wet sediment $=\pi r^{2} \cdot(l=v)$, where $r=$ radius of core $=3.3 \mathrm{~cm}$,

$l=$ length of core segment $=\sim 5.0 \mathrm{~cm}$,

Concentration $(\mu \mathrm{L}$ gas component $/ \mathrm{L}$ wet sediment $)=$ concentration $(\mathrm{ppm}) \times h / v$,

where $h=$ headspace volume $=100 \mathrm{~cm}^{3}$ and $v=$ volume of wet sediment.

For example, methane concentration $=150 \mathrm{ppm}$; if $l=5.0 \mathrm{~cm}$, then $v=170 \mathrm{~cm}^{3}$; methane concentration $(\mu \mathrm{L} / \mathrm{L})=100 \times 100 / 170=59$ $\mu \mathrm{L} / \mathrm{L}$.

No coefficients were applied to correct for the partitioning effects of gas in water.

In the second procedure, the headspace procedure, a measured volume of sediment, usually less than $10 \mathrm{~cm}^{3}$, was placed in a $21-\mathrm{cm}^{3}$ glass vial. The vial was heated to $70^{\circ} \mathrm{C}$, and part of the gas inside the vial was analyzed by gas chromatography. A No. 4 cork borer with a calibrated plunger was used to obtain a measured volume of sediment. The following calculations were used:

Volume of wet sediment measured directly $=v$,

Volume of vial $=21 \mathrm{~cm}^{3}$,

Volume of headspace $=21-v=h$,

Concentration $(\mu \mathrm{L}$ gas component $/ \mathrm{L}$ wet sediment $)=$ concentration $(\mathrm{ppm}) \times(h / v)$. 
For example, methane concentration $=100 \mathrm{ppm}$, $v=5 \mathrm{~cm}^{3}, h=21-v=17 \mathrm{~cm}^{3}$; methane concentration $(\mu \mathrm{L} / \mathrm{L})=100 \times 17 / 5=340$ $\mu \mathrm{L} / \mathrm{L}$.

\section{Alkenones}

We measured the abundances of long-chain alkenones using a Hewlett-Packard Model 5890A Gas Chromatograph equipped with a capillary column and split injection. Because these compounds have long retention times (about 46 and $48 \mathrm{~min}$ ), we set our instrument so as to optimize both response and resolution in this elution region and the higher carbon-number compounds in general ( $>n-C_{15}$ alkanes). Conditions for operating this instrument were as follows:

1. Column, fused silica (cross-linked methyl silicone); film thickness $=0.11 \mu \mathrm{m}$; inner diameter $=0.20 \mathrm{~mm}$; length $=$ $25 \mathrm{~m}$.

2. Conditions, column pressure $=30 \mathrm{psig}$; helium, carrier gas; septum purge $=$ about $4 \mathrm{~mL} / \mathrm{min}$ total flow, including $\mathrm{He}$, 69 psig; air, 35 psig; $\mathrm{H}_{2}, 20$ psig.

3. Temperatures, injector $=250^{\circ} \mathrm{C}$; detector $=300^{\circ} \mathrm{C}$.

4. Temperature program, initial $=30^{\circ} \mathrm{C}$ for $3 \mathrm{~min} ; 10^{\circ} \mathrm{C} /$ $\min$ to $220^{\circ} \mathrm{C} ; 4^{\circ} \mathrm{C} / \mathrm{min}$ to $300^{\circ} \mathrm{C}$; isothermal $=15 \mathrm{~min}$.

5 . Detector, flame ionization.

6. Injection, split mode. Typically, $8 \mu \mathrm{L}$ of hexane solution was injected with a HP $10-\mu \mathrm{L}$ syringe.

\section{Extraction}

A freeze-dried sample was gently ground in a mortar; about $100 \mathrm{mg}$ was weighed out into a 1-dram, screw-top vial using the Rock-Eval transfer funnel. Methylene chloride $(2 \mathrm{~mL})$ was added, and the suspension shaken occasionally for about $2 \mathrm{hr}$. The clear supernatant solution was pipetted into a second vial, and the extraction was repeated with another $1 \mathrm{~mL}$. The combined extract was evaporated under nitrogen blow-down at about $40^{\circ} \mathrm{C}$. BSTFA (about $3 \mu \mathrm{L}$ ) was added, the vial capped and heated at about $60^{\circ} \mathrm{C}$ for $30 \mathrm{~min}$, and then blown down to dryness.

\section{Gas Chromatograph Analysis}

Hexane $(30 \mu \mathrm{L})$ was added, the vial was capped, and then gently maneuvered so that lipid material on the sides of the vial dissolved. Using a $10-\mu \mathrm{L}$ HP syringe, the following volume sequence was drawn up: $1 \mu \mathrm{L}$ hexane, $1 \mu \mathrm{L}$ air, $8 \mu \mathrm{L}$ solution, and air in the needle. This sample was then injected using the standard GC protocol. Quantitation accounted for the weight of dry sediment and the aliquot used in the injection (i.e., 8 out of 30 $\mu \mathrm{L})$. A blind system was run. A major peak was observed at 24.77 min and additional peaks at 18.48-, 20.27-, and 21.40-min retention times.

\section{Data Processing}

Plotting on the HP system gave standardized plots over the intervals 12 to $52 \mathrm{~min}, 12$ to $44 \mathrm{~min}$, and 44 to $52 \mathrm{~min}$, with overprinted retention-time data and forced normalization to bring key peaks on scale. Quantitation was by peak height and handdrawn baseline.

\section{Calibration and Standardization}

Several hydrocarbon and other standard mixtures were used. Difficulties caused by crystallization in the syringe needles were encountered when creating satisfactory solutions of n- $\mathrm{C}_{30}, \mathrm{C}_{32}$, $C_{36^{\prime}}, C_{38^{\prime}}$, and $C_{40^{\prime}}$ (available as $1 \%$ in ethyl benzene, i.e., $10 \mu \mathrm{g} / \mu \mathrm{L})$. A standard was created that contained $20 \mathrm{ng} / \mu \mathrm{L}$ for each component in hexane. Another standard mixture containing $C_{11}$ to $C_{34}$ n-alkanes, plus two high-carbon-number mixtures, $\mathrm{C}_{28}$ to $\mathrm{C}_{40}$, gave the following retention time (RT) data: Alkane (RT in min):
11(9.68), 12(11.29), 13(12.77), 14(14.15), 15(15.45), 16(16.68), 17(17.84), 18(18.95), 19(20.01), 20(21.01), 21(21.98), 22(22.95), 23(23.99), 24(25.13), 25(26.35), 26(27.65), 27(29.03), 28(30.45), 29(31.90), 30(33.37), 32(36.29), 36(41.97), 38(44.96), 40(49.08). Pristane(17.96), Phytane(19.10). Co-injection runs were performed with extracts of Emiliania huxleyi yielding RTs of $C_{37: 3}=45.7$, and $C_{37: 2}=46 \mathrm{~min}$.

The split injection system of the HP instrument afforded reasonable resolution of the $\mathrm{C}_{37: 2}$ and the $\mathrm{C}_{37: 3}$ alkenone peaks, but the high molecular weight "drop off" was considerable, even with a low split ratio (about 1 to 10 ). Quantitation was established using a standard of $\mathrm{n}-\mathrm{C}_{36}$ at $100 \mathrm{ng} / \mu \mathrm{L} ; 8 \mu \mathrm{L}$ was injected.

\section{Organic Pigments}

A semiquantitative estimate of the abundance of two groups of organic pigments in depth profiles was performed during Leg 112. These substances are phaeo-pigments and total carotenoids, which were determined by modifying the method outlined in Parsons et al. (1984). Samples of sediment were freeze dried and ground. Weighed sample aliquots were extracted with acetone in an ultrasonic bath and allowed to settle. Using visible light spectrophotometry (Bausch and Lomb Spectronic 1001), the absorption of the solvent was determined at several wavelengths representing background and signal in 1- $\mathrm{cm}$ glass cuvettes. Results are reported as percentage of absorption, using a method based on that described for seawater by Parsons et al. (1984).

\section{Extraction}

A freeze-dried powdered sample (about $100 \mathrm{mg}$ ) was added to a 1-dram screw-capped vial; aqueous acetone $(2 \mathrm{~mL}, 90 \%$ $\mathrm{vol} / \mathrm{vol}$, i.e., $225 \mathrm{~mL}$ acetone, $25 \mathrm{~mL}$ distilled water) also were added. The capped vial was shaken, set aside $1 \mathrm{hr}$, and then centrifuged.

\section{Methods of Absorption}

The clear, yellow-green supernatant solution was pipetted into a 1-cm (path-length) cell that was previously filled with solvent and having absorption values of zero. We automatically measured absorption at $750,664,642,510$, and $480 \mathrm{~nm}$ using a sequential program in the spectrophotometer.

\section{"Phaeophytin" and "Carotenoid" Contents}

Estimates of the content of the general class of phaeophytin pigments were simplified by subtracting the absorption value at $750 \mathrm{~nm}$ from that at $664 \mathrm{~nm}$. This value was normalized for the sample weight and plotted directly as arbitrary units. A similar approximation was used for the carotenoid abundance datathe values for 750 and $510 \mathrm{~nm}$ were subtracted from those for $480 \mathrm{~nm}$.

\section{Organic and Inorganic Carbon Abundance and Type}

\section{Inorganic and Organic Carbon}

The main carbon analyzer used during Leg 112 was the $\mathrm{CO}_{2}$ Coulometer (Coulometrics Model 5011). Carbon from organic and inorganic sources was converted to $\mathrm{CO}_{2}$. This gas was passed through a coulometer, where it was quantitatively absorbed, reacting with monoethanolamine to form a titratable acid that caused a color indicator to change. The color change was monitored electronically. As transmittance increased, the titration current was activated to stoichiometrically generate base at a rate proportional to the transmittance. The titration current was continually measured and integrated to provide $\mathrm{CO}_{2}$ measurements. The $\mathrm{CO}_{2}$ Coulometer served as the detector for the Carbonate Carbon Apparatus (Coulometrics Model 5030) and the Total Carbon Apparatus (Coulometrics Model 5020). Using the Car- 
bonate Carbon Apparatus, $\mathrm{CO}_{2}$ was generated by treating the sediment with $\mathrm{HCl}$ and gentle heating; the evolved $\mathrm{CO}_{2}$ was transferred to the coulometer by a purified helium stream. Sample size was typically $250 \mathrm{mg}$ of sediment; analysis time was 3 to $7 \mathrm{~min}$. Using the Total Carbon Apparatus, $\mathrm{CO}_{2}$ was produced by the combustion of sediment at about $940^{\circ} \mathrm{C}$ in an oxygen atmosphere. Combustion products were swept through catalysts and scrubbers, and the purified $\mathrm{CO}_{2}$ was measured with the coulometer. Sample sizes ranged from 20 to $60 \mathrm{mg}$ of sediment; analysis time was about $5 \mathrm{~min}$. Organic carbon was determined by difference between total carbon and carbonate carbon.

\section{Type of Organic Matter}

Quality and quantity of organic matter were evaluated during Leg 112 by means of the Delsi-Nermag Rock-Eval II plus total organic carbon (TOC), a whole-rock pyrolysis technique used to identify the type and maturity of organic matter and to detect petroleum potential and oil shows in source rocks. This technique involves a graduated temperature program that first releases volatile hydrocarbons at $300^{\circ} \mathrm{C}$ for $3 \mathrm{~min}$, and then releases hydrocarbons from thermal cracking of kerogen as the temperature increases at $25^{\circ} \mathrm{C} / \mathrm{min}$ from 300 to $600^{\circ} \mathrm{C}$. The total volatile $\left(\mathrm{S}_{1}\right)$ and total pyrolytic $\left(\mathrm{S}_{2}\right)$ hydrocarbons were measured by a flame ionization detector and were reported in milligrams of hydrocarbon per gram of sediment. A maximum temperature $\left(\mathrm{T}_{\max }\right)$ value was obtained that corresponded to the temperature at which kerogen yielded the maximum amount of hydrocarbons during the programmed pyrolysis. During the pyrolysis cycle, $\mathrm{CO}_{2}$ produced from organic matter was trapped from 300 to $390^{\circ} \mathrm{C}$ and analyzed in a thermal conductivity detector $\left(\mathrm{S}_{3}\right)$. The units of $\mathrm{S}_{3}$ were milligrams of $\mathrm{CO}_{2}$ per gram of sediment. In addition, the previously pyrolyzed sample was oxidized to provide additional data needed for calculating the TOC. Rock-Eval parameters were used to calculate Production Index $(\mathrm{PI})=\mathrm{S}_{2} /\left(\mathrm{S}_{1}+\mathrm{S}_{2}\right)$, Petroleum Potential or Pyrolyzed Carbon $(\mathrm{PC})=0.083\left(\mathrm{~S}_{1}+\mathrm{S}_{2}\right)$, Hydrogen Index $(\mathrm{HI})=100\left(\mathrm{~S}_{2}\right) / \mathrm{TOC}$, and Oxygen Index $(\mathrm{OI})=100\left(\mathrm{~S}_{3}\right) /$ TOC. Results are presented as graphs and tables. Sample size was typically $100 \mathrm{mg}$; the fully automated analytical cycle requires about $25 \mathrm{~min}$, and data are presented both graphically and in tabular form.

\section{GEOMICROBIOLOGY SAMPLING DURING LEG 112}

\section{Introduction}

Little information is available regarding the microbiology of deep sea sediments, especially the nature and extent of microbial processes at sediment depths greater than a few meters. This lack of information results from problems of access and of the incubation and handling of samples under conditions almost like those pertaining to in situ, for example, pressure and temperature. Indirect geochemical evidence suggests that microbial activity does continue to considerable depths in these sediments. However, direct microbiological studies will be necessary to answer the question- "a deep microbiology-yes or no?". Shore-based research on Leg 112 samples will be a step in this direction. The following section highlights the sampling program specific to Leg 112 and is not a routine ODP sampling program.

The aim of the overall program was to investigate the distribution of microbial activity and biomass as a continuum with sediment depth, including assessment of the depth at which microbial activity ceases. Future work will assess the presence of different types of microorganisms, and we will try to make cultures with them. This work has direct relevance to the degradation, modification, and in-situ production of organic material in today's marine sediments.
Future shore-based research to be conducted with these samples is as follows:

1. To assess the distribution of the bacterial biomass with depth within the sediments by direct microscopic observation coupled with selective staining, phospholipid determination, and distribution of characteristic biomarker compounds.

2. To measure the microbial activity with depth within the sediment, based on the rate of incorporation of microbial growth substrates. The bacterial groups to be studied are nitrite-respiring and ammonifying, sulfate-reducing, methanogenic, and acetogenic bacteria.

3. To estimate the concentration of specific bacteria and bacterial groups by a Most Probable Number (MPN) technique.

\section{Sampling}

This sampling program incorporated four types of samples:

1. Core sections (whole-round, $10 \mathrm{~cm}$ long; about $300 \mathrm{~cm}^{3}$ ), which were stored under nitrogen at $5^{\circ} \mathrm{C}$ for determining microbial activity later with shore-based culturing experiments.

2 . About $1 \mathrm{~cm}^{3}$ of sediment from the same zone was fixed in a $5 \%$ formalin seawater to determine biomass.

3. A $20-\mathrm{cm}^{3}$-sediment plug, also from this zone was frozen immediately for determining biomass.

4. Interstitial-water samples $\left(6 \mathrm{~cm}^{3}\right)$ at nearby zones were (1) added $(4 \mathrm{~mL})$ to $1 \mathrm{~mL}$ of zinc acetate solution, mixed and stored in our refrigerated room and (2) frozen $(2 \mathrm{~mL})$.

These sampling procedures were developed and improved from the first (Hole 679C) through the second (Hole 680C) to the third and final hole (Hole 681C). The procedure adopted for Hole $681 \mathrm{C}$ is described here, together with brief comments concerning earlier holes. These sites were selected on the basis that they were likely to exhibit continuous sequences of nonlithified, laminated, organic-rich sediments to depths on the order of $100 \mathrm{~m}$.

\section{Initial Sectioning of Drill Cores}

The whole length of the core tube was visually inspected before sectioning. The uppermost part of Section 1 of Core 1 had a semi-fluid consistency down to $1 \mathrm{mbsf}$. Immediately below the mud line, the mud was highly disturbed because of the handling of the core on deck. Each core was usually incomplete. Hence, we recovered the first sample either in the lower part of Section 1 or near the top of Section 2. The rest of the sections had been pre-selected on the basis of depth for sampling a 100 -m hole, i.e., up to seven samples in $1 \mathrm{~m}$, three in the next $9 \mathrm{~m}$, and five in the next $90 \mathrm{~m}$. This bias toward sampling the uppermost part of the core was achieved despite the disturbance in Section 1 of Core 1. We made final decisions about which sections to use for geomicrobiological samples on the core deck; however, we were unable to select according to lithology or by direct comparison with other cores.

The procedure adopted for Hole $681 \mathrm{C}$ was (1) to cut (corecutter tool) the core into sections on the core deck and immediately cap them with plastic caps (no acetone). Those sections selected for microbiological sampling were then carried to the Second-Look Laboratory, where the equipment to further subdivide them had been assembled. Any part of the core needed for other purposes (e.g., interstitial water or gas) was normally taken from the lower end of the section, and the remaining portion capped. This happened on the core deck or the SecondLook Laboratory, as appropriate.

This procedure was followed mostly in the Hole $680 \mathrm{C}$; at Hole $679 \mathrm{C}$, the sectioning and sampling occurred on a table on the core deck, and the sealing was done in the Chemistry Labo- 
ratory. All cutting tools, spatulas, and end caps used were washed clean, dipped in or sprayed with isopropanol to sterilize them, and then allowed to dry just before use. We wore fresh plastic gloves for processing each new core section to minimize crosscontamination.

\section{Core/Section Samples}

The core/section was supported on core stirrups, measured off, and the appropriate 10 -cm-length marked before being cut with the core cutter. Each cut end in turn was trimmed with a palatte knife and immediately closed with an end cap. Trapped air was flushed out from beneath each cap with nitrogen (two or three $50-\mathrm{mL}$ volumes) from a syringe applied to one of a pair of needles (luer lock) inserted at the rim of the cap. The caps were pressed tightly over the core tube and sealed with several layers of black electrical tape. The ends of the core tubes then were dipped briefly into melted paraffin wax, followed by cold water (repeated once). The sealed cores were stored at $5^{\circ} \mathrm{C}$ in the dark. The use of cans as outer protection was initially frustrated by the lack of a shipboard canning tool. The cores from Holes $680 \mathrm{C}$ and $681 \mathrm{C}$ eventually were placed into plastic bags, which were then flushed with nitrogen and sealed by heat. Subsequently (27 November 1986), a canning tool (Ives-Way, Automatic Can Sealer, Model 50) reached the ship, and we used it to can these samples. Earlier, these cans had been prepared with two septa, which permitted the sealed cans to be flushed with nitrogen before storage.

\section{Biomass Samples}

Biomass samples were taken from the cut end of the rest of the section immediately after removing the $10-\mathrm{cm}$ core. The two types of samples were (1) fixed sediment - a spatula was used to take out about $1-2 \mathrm{~cm}^{3}$ of sediment from the center of the cut end; this sample was transferred to a plastic vial containing about $20 \mathrm{~mL}$ of $5 \%$ formalin solution $(250 \mathrm{~mL}$ IAPSO standard seawater to which $30 \mathrm{~mL}$ of formalin [Fisher Formaldehyde solution, $40 \% \mathrm{v} / \mathrm{v}$ containing $10 \%$ to $15 \% \mathrm{vol} / \mathrm{vol}$ methanol] had been added); these vials were stored at $5^{\circ} \mathrm{C}$, except for samples from Hole $679 \mathrm{C}$, which were inadvertently frozen for $24 \mathrm{hr}$; and (2) frozen sediment - a standard $20-\mathrm{cm}^{3}$ plastic core-plug was used to sample the end of the remaining part of the section. The core-plug and its contents were immediately placed into a plastic bag, which was then flushed with nitrogen, heat sealed, and stored at $-20^{\circ} \mathrm{C}$.

\section{Pore-Water Samples}

Sediment samples (whole-round cores) were taken in adjoining or nearby parts of certain sections and squeezed to provide interstitial-water samples (see "Inorganic Geochemistry" section, Site 679 chapter). About $4 \mathrm{~mL}$ of water were added to $100 \mu \mathrm{L}$ of a concentrated solution of mercuric chloride (zinc acetate was not available), mixed, and stored at $5^{\circ} \mathrm{C}$. In addition, $2 \mathrm{~mL}$ were frozen. Both the biomass and pore-water samples were immediately sealed in plastic tubes.

\section{Results}

We encountered several problems with this experiment. Contamination was possible at all stages; namely, during the coring, sectioning, and sealing operations. The sectioning and sealing had to be conducted in the open laboratory, as suitable controlled environmental cabinets and adequate supplies of nitrogen were not available. Temperatures could not be controlled readily. The cores experienced transit through the water column for somewhat less than $1 \mathrm{hr}$, and more time (about $1 \mathrm{hr}$ ) was involved in storage, handling, and cutting. Subsequently, storage was mainly at about $5^{\circ} \mathrm{C}$, but some brief exposures to higher room temperatures may have occurred. We found that waxing the ends of the cores did not cause much heating of the samples. Exposure to air presented the main difficulties. Air pockets penetrated between the core and core-liner during sectioning and cutting, and the cut ends of the core were exposed briefly (a few minutes) before capping, flushing with nitrogen, and final sealing. The presence of hydrogen sulfide in the cores was evidence of their anoxicity. Pressure differences between in-situ values and laboratory values are large, of course, although mitigated by the shallow water depths at the sites. Furthermore, these samples were cored at less than 100 mbsf. Finally, the storage time for the core materials before their arrival in the United Kingdom was expected to be on the order of two months, at a temperature near $5^{\circ} \mathrm{C}$.

Samples from Hole $681 \mathrm{C}$ should be the most reliable, as their collection and treatment were conducted more efficiently. However, depth profiles of the interstitial-water (pore-water) chemistry and the methane contents of the three sites differ considerably from one hole to another. Hence, the microbial populations, although likely to have general similarities, might differ from hole to hole, and careful comparative studies will be necessary. Sulfate-reducing microorganisms should currently dominate all the samples from Holes $679 \mathrm{C}$ and $680 \mathrm{C}$ and the upper seven samples of Hole 681C. Methanogens should dominate in the lower five samples for Hole 681C. However, the deepest sample recovered (at 80 mbsf; Sample 112-681C-9H-6, 40-60 cm) was probably already experiencing replenishment of sulfate from a deep brine, which was discovered at Site 681 (see "Inorganic Geochemistry" section, this chapter) and, hence, sulfate-reducing bacteria may again be active. Detailed cross-correlation of $\mathrm{C}$-holes with other holes from the same sites must await further sampling of these cores at the Gulf Coast Repository.

We collected samples from Hole $679 \mathrm{C}$ first and tried to cap them. However, we could seal them only by using silicon rubber cement and tape, followed within two days by waxing the ends of the covers of the cans. Causes for concern include inadequate sealing, acetic acid vapor from the silicone cement, and temperature variations from 5 to $20^{\circ} \mathrm{C}$.

\section{Conclusions}

Although the present shipboard procedures could be improved, major reorganization and redesigning of these sampling procedures should probably be done by a shipboard geomicrobiologist. Indeed, a clear need exists to coordinate interstitialwater chemistry studies with geomicrobiological biomass and activity measurements, with both undertaken on board ship immediately after core retrieval. For instance, there is a great scope for studies aimed at understanding the origin and methods generating the wide variety of depth profiles of mineralogical, physi$\mathrm{cal}$, and organic and inorganic chemical properties seen in ODP cores (such as those retrieved during Leg 112). To date, the major missing component for understanding sedimentary diagenesis downhole is geomicrobiology. We urgently need to remedy this deficiency, possibly by initiating a leg proposal centered on the problem of early diagenesis. For example, an improved understanding of microbial methane and ethane production and utilization in relation to depth in the sediment could be valuable when deciding whether it is safe to drill (see Claypool and Kaplan, 1974). Furthermore, a clear and unequivocal demonstration of the downward extent of the biosphere to considerable depths in oceanic sedimentary columns could have a major impact on the scientific community and the general public.

\section{INORGANIC GEOCHEMISTRY}

Interstitial-water samples (either squeezed from whole-round sediment samples 5 to $10 \mathrm{~cm}$ long or recovered from the in-situ water samples) were analyzed on board ship for $\mathrm{pH}$, alkalinity, salinity, calcium, magnesium, sulfate, chlorinity, silica, ammo- 
nia, and phosphate. Water was squeezed from the sediments using a stainless-steel press at a maximum of $40,000 \mathrm{psi}$, collected in plastic syringes, and filtered through prewashed millipore filters with a nominal pore diameter of $0.45 \mathrm{~m}$. The primary standard for water analyses was IAPSO standard seawater.

Alkalinity was determined using a Metrohm 605 autotitrator pH-meter calibrated with NBS (National Bureau of Standards) $4.01,6.86$, and $7.41 \mathrm{pH}$ buffer solutions. All pH measurements were conducted in conjunction with alkalinity measurements. A Brinkmann combination $\mathrm{pH}$ electrode was used. Samples were tested for $\mathrm{pH}$ and subsequently titrated for alkalinity with $0.1 \mathrm{~N}$ $\mathrm{HCl}$. Our computer used the Gran function to calculate alkalinity. We routinely used $5-\mathrm{cm}^{3}$ water samples. To standardize alkalinity, $\mathrm{NaHCO}_{3}$ solutions of 2.5 to $25 \mathrm{mmol} / \mathrm{L}$ were used.

Salinity values were determined from refractive indices measured by an AO Scientific Instruments optical refractometer; results were provided directly in grams per kilograms.

Sulfate concentrations were measured using the Dionex 2120i Ion Chromatograph. Standardization was based on analyses from IAPSO and standards prepared by J. M. Gieskes. All analyses were conducted using a $0.2-\mathrm{cm}^{3}$ sample diluted to $100 \mathrm{~cm}^{3}$ with low-conductivity water.

Chlorinity, $\mathrm{Ca}^{2+}$, and $\mathrm{Mg}^{2+}$ concentrations in the squeezed water were analyzed by microtitration after standardization using IAPSO standard seawater. Calcium was determined using a mini-version of Tsunogai et al.'s method (1968). To analyze magnesium, first a titration was performed for total alkaline earths $\left(\mathrm{Ca}^{2+}, \mathrm{Mg}^{2+}\right.$, and $\left.\mathrm{Sr}^{2+}\right)$. The $\mathrm{Ca}^{2+}$ plus $\mathrm{Sr}^{2+}$ value then was subtracted from the total. Dissolved silica, phosphate, and ammonia concentrations were determined spectrophotometrically. All analytical methods for interstitial waters followed the procedures described in Gieskes and Peretsman (1986), who also described methods of preparing standards and reagents for the various analyses.

\section{PHYSICAL PROPERTIES}

During Leg 112 physical properties were measured to determine their relationship to various sediment facies. Because of their dominant influence on seismic records, detailed physical and stratigraphic data in conjunction with digital seismic profiles were used to decipher the origin of reflectors in seismic records. The shipboard physical-properties program for Leg 112 included the measurements that follow.

\section{Gamma Ray Attenuation Porosity Evaluator}

The Gamma Ray Attenuation Porosity Evaluator (GRAPE) was used in the routine manner to log the whole-core sections. The raw data were logged on the PRO-350 and subsequently transferred to the VAX for processing. Standard procedures were used for calibration as described by Boyce (1976).

\section{$\boldsymbol{P}$-Wave Logger}

The compressional-wave, whole-core logging tool $(P$-Wave Logger) introduced during Leg 108 was operated in conjunction with the GRAPE to log compressional-wave velocity of wholecore sections. A typical sampling interval was $2 \mathrm{~mm}$. The system and procedure were described in detail by Ruddiman, Sarnthein, et al., (1988). We observed that the $P$-Wave Logger (PWL) did not provide good data in XCB cores or in APC cores when the sediments were gassy. Much of the collected data was discarded when we noted that the amplitude of the received signal was zero, even though a value of velocity was obtained. The most obvious example of this occurred when a value of velocity in the range of $1650 \mathrm{~m} / \mathrm{s}$ was obtained while a section of empty liner was passing through the transducers. The amplitude of the received signal was zero, yet a "velocity" was obtained. Upon more detailed examination of the data records, we observed that the same phenomena occurred in gassy sediments and in XCB cores. All such data have been omitted in the site chapters.

\section{Velocity}

Compressional-wave velocities were measured where possible on split cores using the Hamilton Frame. In general, most of the sediments recovered were unsuitable for this test, as they were either too soft or too fractured to yield good samples. The operating procedure and calibration of the Hamilton Frame was conducted in a manner similar to that described by Boyce (1976).

\section{Index Properties}

This suite of data provided gravimetric parameters, such as water content, porosity, bulk density, and grain density. Samples of approximately $10 \mathrm{~cm}^{3}$ (one for every other section) were taken routinely from freshly split cores (more if time permitted) down the first hole at each site and placed in pre-calibrated aluminum containers. Additional samples were obtained from adjacent holes to supplement the data set at intervals where the GRAPE and/or PWL indicated significant local fluctuations in density or velocity. Wet- and dry-bulk weights were determined on board ship using the motion-compensating Scitech electronic balance to an accuracy of $\pm 0.01 \mathrm{~g}$. Sample volumes were determined for both the wet and dry samples using the Penta Pycnometer. The samples were oven-dried to constant weight. Samples taken for other purposes also furnished water contents; these data sets were merged.

\section{Vane Shear Strength Measurements}

Problems were encountered with the data for the first site that was obtained using the new motorized vane/plotter system. Mechanical problems that could not be remedied on board ship required us to use the old Wykham-Farrance vane apparatus for the remainder of Leg 112. The use of this equipment was thoroughly described by Boyce (1977).

\section{Thermal Conductivity}

Thermal conductivity was measured by the needle probe method (Von Herzen and Maxwell, 1959). Measurements were controlled by the Thermcon unit manufactured by Woods Hole Oceanographic Institution. Cores were allowed to equilibrate in the laboratory at least $4 \mathrm{hr}$ before testing to attain thermal equilibrium. In most cases, measurements were performed on the whole-round samples by inserting probes perpendicular to the cores. When the cores were split before thermal equilibrium, probes were inserted from the ends of the sections parallel to the cores. Measurement time was $6 \mathrm{~min}$ for whole-round samples and $3 \mathrm{~min}$ for split samples. The two methods were compared using Hole $682 \mathrm{~A}$ samples; the difference between thermal conductivity values using both methods was about $0.05 \mathrm{~W} / \mathrm{m} \cdot \mathrm{K}$ on average.

\section{DOWNHOLE LOGGING TOOLS USED DURING LEG 112}

All tools were the property of Schlumberger Well Services. These tools are used commercially for petroleum exploration and, for the most part, are well-described in the literature (Serra, 1984).

Gamma Spectrometry (GST) - pulsed neutron-induced capture gamma-ray spectrometer using a NaI(Tl) detector. Spectral yields for elements silicon, calcium, iron, hydrogen, chloride, and sulfur are the raw data of the GST, which was run solely in capture mode during Leg 112. A total formation neutron capture cross-section was also measured. The GST yields were converted to elemental weight percent during post-logging interpretations. 
Aluminum Clay (ACT) - This prototype was being field tested by Schlumberger during Leg 112 . Neutron-induced (Cf chemical source) late gamma-ray spectrometry used two $\mathrm{NaI}$ (Tl) detectors to correct for natural gamma-ray activity. Yields for aluminum and manganese are just now being supplied. Calibration to elemental weight percent was performed by taking irradiated core samples of known volume and density and measuring their gamma-ray output while placed in a jig attached to the logging tool (generally after logging).

Natural Gamma Spectrometry (NGT) - Total natural gamma-ray activity was measured with a $\mathrm{NaI}(\mathrm{Tl})$ detector using five energy windows. Contributions from uranium, thorium, and potassium were determined separately; weight percents of these elements were supplied in real time.

Long Spacing Sonic (LSS) - Acoustic slowness was measured using two high-frequency transmitters (in the range of 20 $40 \mathrm{kHz}$ ) and two receivers. Spacings of 8,10 , and $12 \mathrm{ft}$ between receiver-transmitter pairs allowed us to correct for slight tilting of the centralized tool. Four measured waveforms were digitized uphole, and data were stored on magnetic tape. Post-logging analysis of waveform data can provide shear and compressional slowness when hole and formation conditions permit. The diameter of a hole (caliper) was measured with a potentiometer attached to one of the centralizers.

Dual Induction (DIT) - Two high-frequency electromagnetic transmitter-receiver pairs were used to measure formation electrical conductivity. Deep and medium depths of investigation were achieved by the spacings between receivers and transmitters. A shallow (invasion zone) conductivity also was determined by measuring the decrease in voltage in a spherically focused current loop that passed through the formation.

Lithodensity (LDT) - Electron density of a formation and photoelectric effects were measured by spectral analysis of gamma-ray attenuation. A Cesium (chemical) gamma-ray source and two $\mathrm{NaI}(\mathrm{Tl})$ detectors were used. Bulk density of a formation was determined by assuming 2.0 nucleons per electron. The detectors and source were mounted on a skid that must contact the borehole wall for valid results. Empirical corrections must be applied to the bulk density measurement to account for caked mud on the borehole wall (not applicable to Leg 112 conditions).

Compensated Neutron (CNL) - An americum/beryllium chemical neutron source and two thermal neutron detectors were used to measure neutron attenuation by the formation. Porosity was determined from dual detector count rates using the most appropriate empirical transform for quartz, calcite, or dolomite. Determining porosity in mixed lithologies often requires post-logging analysis.

\section{LEG 112 PROCEDURE FOR ESTIMATING THERMAL CONDUCTIVITY FROM WIRELINE LOGGING DATA}

Studies of thermal processes in the earth's interior require temperature and heat-flow data to constrain models and provide basic information for theories intended to explain the geology, tectonics, and geophysical phenomena observed at the earth's surface. For this reason, geophysicists have made great efforts to develop a variety of methodologies and techniques to measure or estimate the temperature, thermal conductivity, and other material properties of the outermost crustal "layers" of the earth.

As part of this ongoing effort, one of Leg 112's main objectives was to measure thermal conductivity and other sediment physical properties in cores taken from the drilled holes. These measurements were performed immediately after a core was brought to the ship's laboratories. Thermal conductivity was measured using the Von Herzen needle method (see "Physical Properties" section, this chapter).
Regardless of the measurements' accuracy, this procedure gives values with relatively high dispersion, reflecting in some measure the degree of local heterogeneity of the sediments and their fine structure, environmental conditions such as diagenetic alteration, changes produced by retrieving the core from great depths, and sample disturbance. In many instances, core recovery contains gaps. Despite these problems, the needle method gives overall consistent results.

An alternative procedure that lessens the severity of these problems is the methodology used by Ocola (1985) to estimate in-situ thermal conductivity using wireline logging data from land wells. This method requires a total-porosity and formation factor; it works well for "clean sands."

Leg 112 provided a unique opportunity to investigate whether this method, used in land wells to estimate heat flow in a Mesozoic sedimentary basin, could be used for oceanic Quaternary and/or Tertiary deposits by using the wireline-logging data obtained from drilled holes.

The log data-acquisition system used in Leg 112 comprises Long Spaced Sonic, Caliper, Dual Induction, Gamma Ray, Gamma Spectrometry, two-temperature logs at different times, Lithodensity, and Compensated Neutron logs. From these records, the procedure used neutron porosity, formation resistivity, hole fluid temperatures, hole dimension, salinity index (SIR), and as complementary information, photoelectric effect absorption index (PEF), sonic-slowness (inverse of velocity), and bulk density.

Currently, the computation algorithm replaces the logged SIR with the interstitial-water salinity data (see "Organic Geochemistry" section, this chapter) because the logged SIR calibration constants are not yet available.

Quartz dominates the lithology of the first stratigraphic units drilled at Sites 679 and 685 . Thus, the lithology can be considered a "clean sand" equivalent when computing the formation factor. For such a case, this factor can be found using the ratio between formation and fluid resistivities. Formation resistivity can be read from the logs. Fluid resistivity is computed from the interstitial-fluid salinity and the hole temperature for the same depth, using Dresser Atlas (1982) and Schlumberger's (Serra, 1984) equations and factors. However, for all practical purposes, total salinity and the sodium chloride equivalent salinity gave the same results.

The neutron porosity, as given by the Schlumberger logging tool, only compensated for the bit size (L. Geiser, pers. comm.), which is 13 in. in diameter. On the other hand, the maximum hole diameter the caliper can sense is about $14.5 \mathrm{in}$. This implies a maximum compensation of about $2 \%$ to the apparent porosities read from the logs. Moreover, the lime-based neutron porosity has to be reduced to sand-based porosity, which involves adding a $4 \%$ correction for porosities greater than $7 \%$ (see Serra's 1984 and Dresser Atlas' 1982 graphs).

Formation thermal conductivity was computed using the compensated porosity, the computed formation factor, and equations from Woodside and Messmer (1961) and Sugawara and Yoshizawa (1962) with the modified coefficients given by Ocola (1985).

In general, values derived with the modified Woodside-Messmer equation are slightly higher than those given by that of Sugawara and Yoshizawa. The final value reported is the average of these two results.

\section{Formation Temperature and Geothermal Gradient}

The formation temperature as a function of depth is the second most important factor when computing heat flow. The logging conducted during Leg 112 provided the minimum temperature information for use with the Lachenbruch and Brewer for- 
mula (Serra, 1984; Dresser Atlas, 1982). This formula was used to estimate the probable temperature evolution with time as the formation comes to thermal equilibrium after circulation of cold drilling fluids.

Thus, temperatures are extrapolated to the stabilized formation temperature at each depth where discrete measurements were performed. In addition to drilling time at each depth, the application of such a formula required the time the fluid circulation stopped.

Estimated formation temperatures allowed us to compute the formation thermal gradient as a function of depth. However, because of the short interval between the two logging times, the extrapolated temperature became sensitive to the temperature change between both logging runs.

A more stable and reliable formation temperature could be obtained if three, instead of two, temperature profiles were conducted after stopping the fluid circulation. However, results can also be improved by applying more involved mathematical procedures when describing the temperature evolution with time, such as those that account for a prescribed radial temperature distribution and a description of radial heat conduction (see Burch and Langseth, 1981).

\section{HEAT FLOW}

Determining heat flow requires thermal conductivity and temperature gradient data. Shipboard thermal conductivities were measured by the needle probe method (see "Physical Properties" section, this chapter). The thermal conductivity values measured in the laboratory were corrected to in-situ temperature and pressure conditions following Ratcliffe (1960).

\section{Temperature}

During Leg 112, temperature data were obtained using three different methods. These are described next.

\section{APC Tool}

The Von Herzen APC (advanced piston corer) heat-flow instrument was used for measuring temperature while taking APC cores. This tool consists of a temperature recorder and a battery pack that are installed in the cutting shoe of APC (Horai and Von Herzen, 1986). During core sampling, the tool can record sediment temperatures, which are not affected by drilling. Two instruments of this type were available on board the JOIDES Resolution. However, one instrument recorded erratic data or no data at all at the first two sites. Thus, the instrument was not used at following sites.

Usually, sediment temperature was recorded for about $10 \mathrm{~min}$. The temperature record indicates a disturbance owing to heat caused by friction associated with penetration of the APC into the sediment. The equilibrium formation temperature was extrapolated from the decay curve of the disturbance using Horai and Von Herzen's theory (1986).

The APC tool was also run during pore-water sampling by attaching the APC cutting shoe to the pore-water sampler. In this case, the tool was kept in the sediment for about $40 \mathrm{~min}$. However, the pore-water sampler with a large heat capacity dominated the temperature variation of the system and prevented the temperature from approaching equilibrium. In addition, heat conduction through the pore-water sampler may be considerable when the penetration depth of the tool is shallow and water may flow in along the surface of the sampler. All these factors can lower the temperature of the APC cutting shoe.

The T-probe is a temperature recorder that can be housed in the pressure case of the Barnes pore-water sampler (Yokota et al., 1980). The temperature sensor is installed in a probe at the nose of the sampler. During pore-water sampling, a sediment temperature was recorded for $20-40 \mathrm{~min}$. As the pore-water sampler was dropped freely from the deck, penetration depth of the sediment is uncertain. During Sites 680 and 681, the temperature recorded by the T-probe was erratic, mainly because of malfunction of the electronics package and a defect in the temperature sensor. During Sites 686 and 687, we obtained good temperature records. However, after measuring we saw that there was a problem with the part connecting the temperature sensor to the recorder, which caused drifts in the temperature records. The drifts were corrected using the temperature records in the water by running both the APC tool and the T-probe. Temperature recorded in the sediment was extrapolated to equilibrium following the method of Bullard (1954).

\section{Temperature Logging}

In the holes that were logged, both temperature and depth profiles were obtained at two different times after drilling was completed. As temperatures were disturbed by circulation of cold drilling fluid, the stabilized formation temperature could be extrapolated from the two temperature profiles. The equilibrium temperature was estimated by assuming that the drilling disturbance was represented by a line heat source in an infinite medium (Bullard, 1947; Lachenbruch and Brewer, 1959). In addition to the drilling time at each depth, applying the theory also required the time when fluid circulation stopped.

\section{REFERENCES}

Akiba, F., 1985. Middle Miocene to Quaternary diatom biostratigraphy in the Nankai trough and Japan trench, and modified lower Miocene through Quaternary diatom zones for middle-to-high latitudes of the North Pacific. In Kagami, H., Karig, D. E., Coulbourn, W. C., et al., Init. Repts. DSDP, 87: Washington (U.S. Govt. Printing Office), 483-554.

Akiba, F., and Yanagisawa, Y., 1985. Taxonomy, morphology and phylogeny of the Neogene diatom zonal marker species in the middle-tohigh latitudes of the North Pacific. In Kagami, H., Karig, D. E., Coulbourn, W. C., et al., Init. Repts. DSDP, 87: Washington (U.S. Govt. Printing Office), 483-554.

Barron, J., 1985. Late Eocene to Holocene diatom biostratigraphy of the equatorial Pacific Ocean, Deep Sea Drilling Project Leg 85. In Mayer, L., Thayer, F., Thomas, E., et al., Init. Repts. DSDP, 85: Washington (U.S. Govt. Printing Office), 413-456.

Bārron, J., Keller, G., and Dunn, D., 1985a. A multiple microfossil Biochronology for the Miocene. Geol. Soc. Am. Mem., 163:21-36.

, 1985b. Synthesis of biostratigraphy, Central Equatorial Pacific, Deep Sea Drilling Project Leg 85: refinement of Oligocene to Quaternary biochronology. In Mayer, L., Thayer, F., Thomas, E., et al., Init. Repts. DSDP, 85: Washington (U.S. Govt. Printing Office), 905-934.

Bates, R. L., and Jackson, J. A. (Eds.), 1982. Glossary of Geology, Second Edition: Falls Church (Am. Geol. Inst.)

Berggren, W. A., et al., 1985. Cenozoic geochronology. Geol. Soc. Am. Bull., 96:1407-1418.

Blow, H. M., 1969. Late middle Eocene to Recent planktonic foraminiferal biostratigraphy. In Brönnimann, R., and Renz, H. H. (Eds.), Proc. 1st Inte. Conf. Planktonic Microfossils, Geneva, 1967, 1:199421.

Boyce, R. E., 1976. Definitions and laboratory techniques of compressional sound velocity parameters and wet-water content, wet bulk density and porosity parameters by gravimetric and gamma ray attenuation techniques. In Schlager, S. O., Jackson, E. D., et al., Init. Repts. DSDP, 33: Washington (U.S. Govt. Printing Office), 931958.

Bullard, E. C., 1947. The time necessary for a borehole to attain temperature equilibrium. Mon. Not. Roy. Astr. Soc., Geophys. Suppl., $5: 127-130$.

1954. The flow of heat through the floor of the Atlantic Ocean. Proc. Roy. Soc. London, A222:408-429.

Burch, T. K., and Langseth, M. G., 1981. Heat flow determination in the DSDP boreholes near the Japan Trench. J. Geophys. Res., 86: 9411-9419. 
Claypool, G. E., and Kaplan, I. R., 1974. The origin and distribution of methane in marine sediments. In Kaplan, I. R. (Ed.), Natural Gases in Marine Sediments: New York (Plenum Press), 99-139.

Dean, W., Leinen, M., and Stow, D.A.V., 1985. Classification of deepsea fine-grained sediments. J. Sed. Petrol., 55:250-256.

Dresser Atlas, 1982. Well Logging and Interpretation Techniques: (Dresser Industry Inc.).

Fenner, J., 1984. Eocene-Oligocene planktic diatom stratigraphy in the low latitudes and the high southern latitudes.

, 1985. Late Cretaceous to Oligocene planktic diatoms. In Bolli, H., et al., Plankton Stratigraphy, Cambridge (Cambridge Univ. Press), 713-762.

Gartner, S., 1977. Calcareous nannofossil biostratigraphy and revised zonation of the Pleistocene, Marine Micropaleontol., 2:1-25.

Gieskes, J, M., and Peretsman, G., 1985. Water Chemistry Procedures on the Sedco 471-Some Comments. ODP Tech. Note, 5.

Horai, K., and Von Herzen, R. P., 1986. Measurement of heat flow on Leg 86 of the Deep Sea Drilling Project. In Heath, G. R., Burckle, L. H., et al., Init. Repts. DSDP, 86: Washington (U. S. Govt. Printing Office), 759-777.

Ingle, J., 1973. Biostratigraphy and paleoecology of early Miocene through early Pleistocene benthonic and planktonic foraminifera, San Joaquin Hills-Newport Bay, Dana Point area, Orange County, California. Soc. Econ. Paleontol. Mineral. Guidebook, Field Trip 1, 18-38.

1980. Cenozoic paleobathymetry and depositional history of selected sequences within the Southern California continental borderland. Cushman Found. Spec. Pub., 19:163-195.

Ingle, J., Keller, G., and Kolpack, R., 1980. Benthic foraminiferal biofacies, sediments and water masses of the southern Peru-Chile Trench area, southeastern Pacific Ocean. Micropaleontology, 26:113-150.

Jenkins, D. G., and Orr, W. N., 1972. Planktonic foraminiferal biostratigraphy of the eastern equatorial Pacific DSDP Leg 9. In Hays, J. D., et al., Init. Repts. DSDP, 9: Washington (U.S. Govt. Printing Office), 1060-1193.

Lachenbruch, A. H., and Brewer, M. C., 1959. Dissipation of the temperature effect in drilling a well in Arctic Alaska. U. S. Geol. Surv. Bull., 1083-C:73-109.

Locker, S., and Martini, E., 1986a. Silicoflagellates and some sponge spicules from the southwest Pacific, DSDP 90. In Kennett, J. D., von der Borch, C. C., et al., Init. Repts. DSDP, 90 (Pt. 2): Washington (U.S. Govt. Printing Office), 887-924.

Locker, S., and Martini, E., 1986b. Ebridians and actiniscidians from the southwest Pacific, DSDP 90. In Kennett, J. D., von der Borch, C. C., et al., Init. Repts. DSDP, 90 (Pt. 2): Washington (U.S. Govt. Printing Office), 939-951.

Martini, E., 1971. Standard Tertiary and Quaternary calcareous nannoplankton zonation. Proc. 2nd Planktonic Conf., Rome, 1970 (Vol. 2); Rome (Edizione Tecnosciencia), 739-785.

Martini, E., and Mueller, C., 1976. Eocene to Pleistocene silicoflagellates from the Norwegian-Greenland Sea (DSDP Leg 38). In Thalwani, M., Udintsev, G., et al., Init. Repts. DSDP, 38: Washington (U.S. Govt. Printing Office), 857-895.

1986. Current Tertiary and Quaternary calcareous nannoplankton stratigraphy and correlations. Newsl. Stratigr., 16:99-112.

Matthews, D. J., 1939. Tables of velocity of sound in pore water and in sea water: London (Admirality, Hydrographic Dept.).

Nigrini, C., 1971. Radiolarian zonation in the Quaternary of the equatorial Pacific Ocean. In Funell, B. M., and Riedel, W. R. (Eds.), The Micropaleontology of Oceans: Cambridge (Cambridge Univ. Press), 443-461.
Ocola, L., 1985. Heat flow in the northeastern Peru Maranon Basin. Proc. Second Am. Symp. Cogeodata, Pap., 20.

Okada, H., and Bukry, D., 1980. Supplementary modification and introduction of code numbers to the low-latitude coccolith biostratigraphic zonation (Bukry, 1973 and 1975), Mar. Micropaleontol., 5: 321-325.

Parsons, T. R., Maita, Y., and Lalli, C. M., 1984. A Manual of Chemical and Biological Methods for Seawater Analysis: Oxford (Pergamon Press).

Perch-Nielsen, K., 1975. Late Cretaceous to Pleistocene silicoflagellates from the southern Southwest Pacific, DSDP Leg 29. In Kennett, J. P., Houtz, R. E., et al., Init. Repts. DSDP, 29: Washington (U.S. Govt. Printing Office), 677-721.

Poore, R. Z., et al., 1984. Late Cretaceous-Cenozoic magnetostratigraphic and biostratigraphic correlations for the South Atlantic Ocean. In Hsü, K. J., La Brecque, J. L., et al., Init. Repts. DSDP, 73: Washington (U.S. Govt. Printing Office), 645-655.

Ratcliffe, E. H., 1960. The thermal conductivities of ocean sediments. J. Geophys. Res., 65:1535-1541.

Resig, J., 1981. Biogeography of benthic foraminifera on the northern Nazca Plate and adjacent continental margin. Geol. Soc. Am. Mem., 154:619-666.

Riedel, W. R., and Sanfillippo, A., 1978. Stratigraphy and evolution of tropical Cenozoic radiolarians. Micropaleontology, 23:81-96.

Ruddiman, W., Sarthein, M., et al., 1988. Proc. ODP, Init. Repts., 108: College Station, TX (Ocean Drilling Program).

Schlanger, S. O., Jackson, E. D., Kaneps, A., and Serocki, S. T., 1976. Introduction and explanatory notes. In Schlanger, S. O., Jackson, E. D., et al., Init. Repts. DSDP, 33: Washington (U.S. Govt. Printing Office), 5-24.

Schrader, H. J., 1971. Selektive Lösung planktischer Diatomeen im Seegebiet zwischen $15-43^{\circ}$ nördlicher Breite und $8-30^{\circ}$ westlicher Länge. In Farinacci, A. (Ed.), Proc. 2nd Planktonic Conf.: Rome (Edizioni Tecnosciencia), 1139-1147.

Schrader, H.-J., and Gersonde, R., 1978. Diatoms and silicoflagellates. Utrecht Micropaleontol. Bull., 17:129-176.

Serra, O., 1984. Fundamentals of Well Log Interpretation, 1. The Acquisition of Logging Data: Amsterdam (Elsevier).

Sugawara, A., and Yoshizawa, Y., 1962. An experimental investigation on the thermal conductivity of consolidated porous materials. $J$. Appl. Phys., 33:3135-3138.

Tsunogai, S., Nishimura, M., and Nakaya, S., 1968. Complete metric titration of calcium in the presence of large amounts of magnesium. Tolanta, 15:385-390.

Von Herzen, R. P., and Maxwell, A. E., 1959. The measurement of thermal conductivity of deep-sea sediments by a needle-probe method. J. Geophys. Res., 64:1557-1563.

Wentworth, C. K., 1922. A scale of grade and class terms of clastic sediments. J. Geol., 30:377-390.

Wentworth, C. K., and Williams, H., 1932. The classification and terminology of the pyroclastic rocks. Rep. Comm. Sedimentation, Bull. Nat. Res. Council (U.S.), 80:10-53.

Woodside, W., and Messmer, J. H., 1961. Thermal conductivity of porous media in unconsolidated sands. J. Appl. Phys., 32:1688-1699.

Yokota, T., Kinoshita, H., and Uyeda, S., 1980. New DSDP (Deep Sea Drilling Project) downhole temperature probe utilizing IC RAM (Memory) elements. Bull. Earth. Res. Inst., 55:75-88.

Ms 112A-103 